
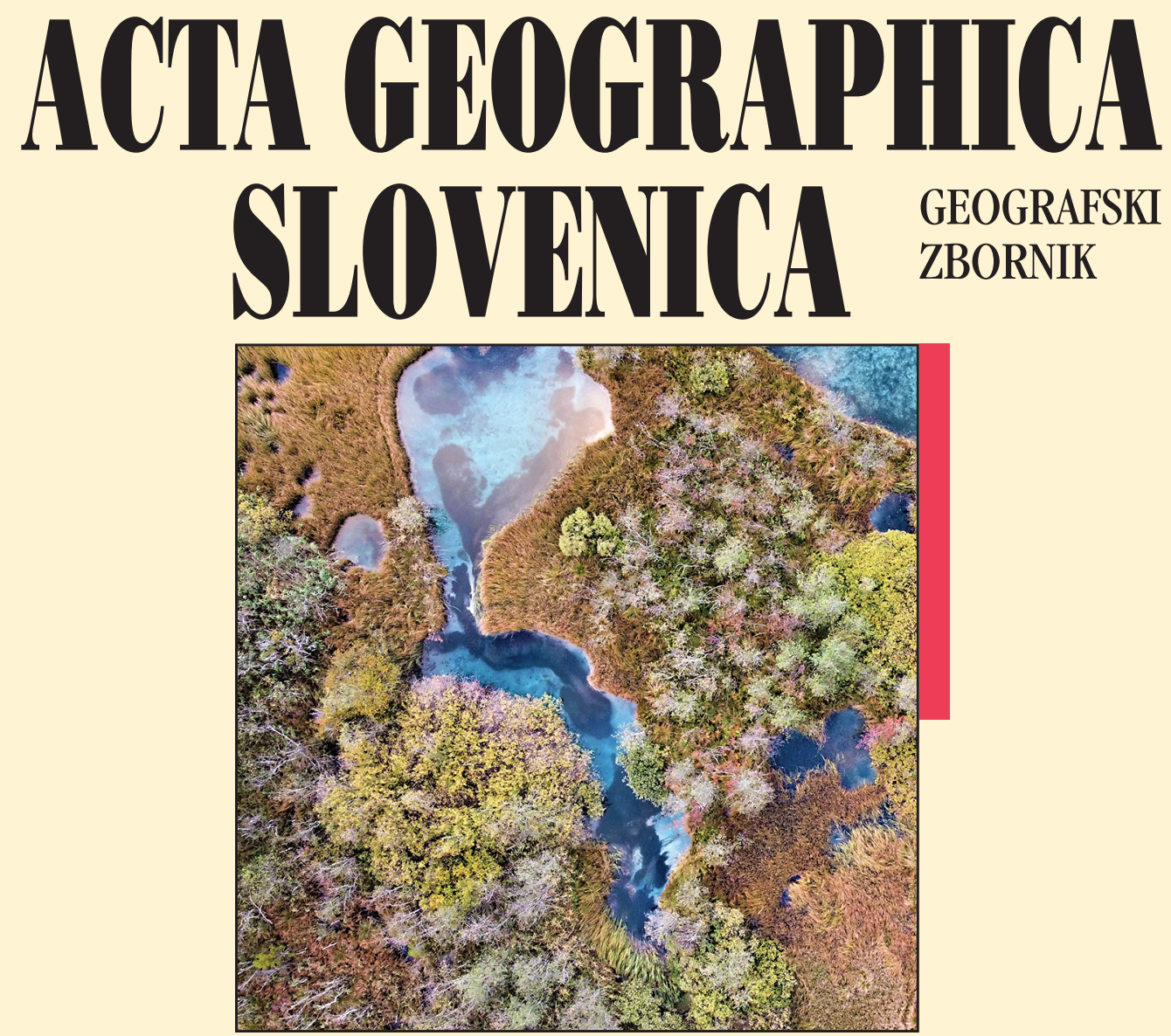


\section{ACTA GEOGRAPHICA SLOVENICA GEOGRAFSKI ZBORNIK 61-2 • 2021}

\section{Contents}

Đorđije VASILJEVIĆ, Milica BEGAN, Miroslav VUJIČIĆ, Thomas HOSE, Uglješa STANKOV

Does geosite interpretation lead to conservation? A case study of the Sićevo Gorge (Serbia)

Gabrijela POPOVIĆ, Dragiša STANUJKIĆ, Predrag MIMOVIĆ, Goran MILOVANOVIĆ, Darjan KARABAŠEVIĆ, Pavle BRZAKOVIĆ, Aleksandar BRZAKOVIĆ

An integrated SWOT - extended PIPRECIA model for identifying key determinants of tourism development: The case of Serbia

Robert KALBARCZYK, Eliza KALBARCZYK

Precipitation variability, trends and regions in Poland: Temporal and spatial distribution in the years 1951-2018

Ivana CRLJENKO, Matjaž GERŠIČ

A comparison of the beginnings of exonym standardization in Croatian and Slovenian

Tadej BREZINA, Jernej TIRAN, Matej OGRIN, Barbara LAA

COVID-19 impact on daily mobility in Slovenia

Maruša GOLUŽA, Maruška ŠUBIC-KOVAČ, Drago KOS, David BOLE

How the state legitimizes national development projects: The Third Development Axis case study, Slovenia

Tin LUKIĆ, Tanja MICIĆ PONJIGER, Biljana BASARIN, Dušan SAKULSKI, Milivoj GAVRILOV, Slobodan MARKOVIĆ, Matija ZORN, Blaž KOMAC, Miško MILANOVIĆ, Dragoslav PAVIĆ, Minučer MESAROŠ, Nemanja MARKOVIĆ, Uroš DURLEVIĆ, Cezar MORAR, Aleksandar PETROVIĆ Application of Angot precipitation index in the assessment of rainfall erosivity: Vojvodina Region case study (North Serbia)

Janij OBLAK, Mira KOBOLD, Mojca ŠRAJ

The influence of climate change on discharge fluctuations in Slovenian rivers

Vladimir STOJANOVIĆ, Dubravka MILIĆ, Sanja OBRADOVIĆ, Jovana VANOVAC, Dimitrije RADIŠIĆ

The role of ecotourism in community development: The case of the Zasavica Special Nature Reserve, Serbia

Marko V. MILOŠEVIĆ, Dragoljub ŠTRBAC, Jelena ĆALIĆ, Milan RADOVANOVIĆ Detection of earthflow dynamics using medium-resolution digital terrain models: Diachronic perspective of the Jovac earthflow, Southern Serbia

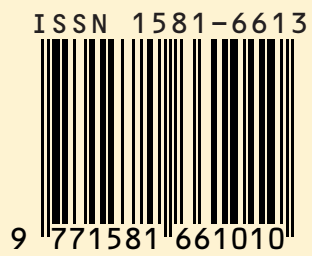




\section{PRECIPITATION VARIABILITY, TRENDS AND REGIONS IN POLAND: TEMPORAL AND SPATIAL DISTRIBUTION IN THE YEARS 1951-2018}

Robert Kalbarczyk, Eliza Kalbarczyk

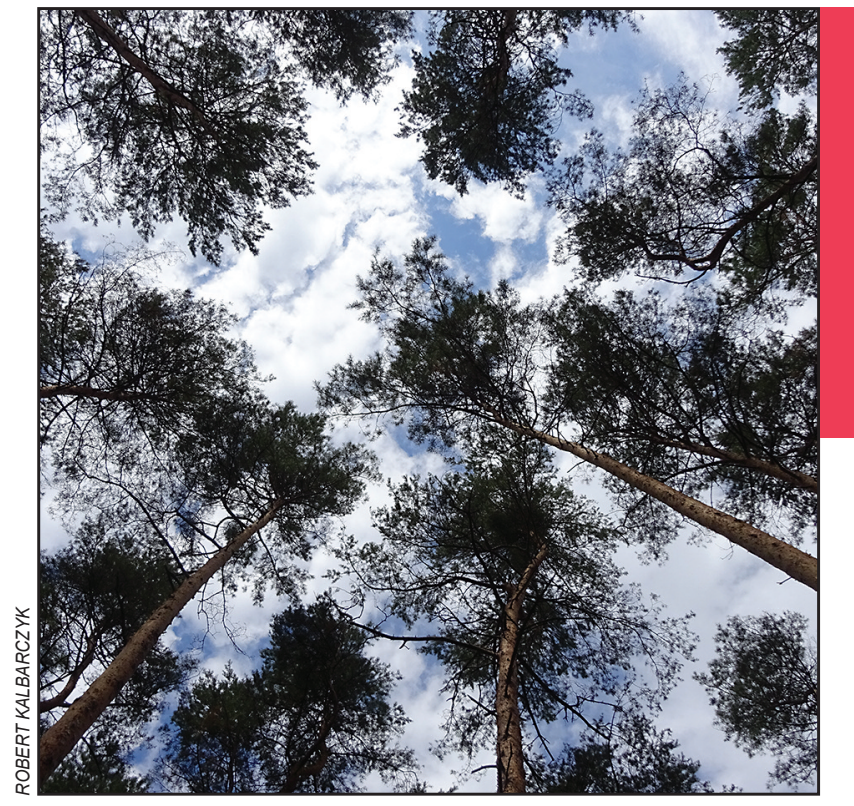

Crowns of Scots pine trees in the clouds. 
DOI: https://doi.org/10.3986/AGS.8846

UDC: 913:551.435.11:502.13(497.11)

COBISS: 1.01

Robert Kalbarczyk ${ }^{1}$, Eliza Kalbarczyk ${ }^{2}$

\title{
Precipitation variability, trends and regions in Poland: Temporal and spatial distribution in the years 1951-2018
}

\begin{abstract}
The goals of this work were to assess differences in precipitation totals (Pr) in Poland in both time and space and to distinguish regions based on precipitation variability in the years 1951-2018. To assess precipitation conditions, the study used statistical and spatial analyses implemented in ArcGIS Desktop and STATISTICA software. The largest number of significant, positive correlations describing the linear Pr trend were found for March. The lowest monthly Pr, which represents only approximately $6 \%$ of the multi-year precipitation totals, was recorded in October 1951; the highest monthly Pr, which represents as much as approximately $355 \%$ of the multi-year precipitation totals, was recorded in October 1974 . The study distinguished three precipitation regions of Poland.
\end{abstract}

KEY WORDS: climate change, precipitation conditions, number of days with precipitation, precipitation regions, Poland.

\section{Spremenljivost, trendi in območja padavin na Poljskem: časovna in prostorska porazdelitev med letoma 1951 in 2018}

POVZETEK: V članku so proučene razlike v skupni količini padavin na Poljskem v času in prostoru, na podlagi česar so določena glavna padavinska območja med letoma 1951 in 2018. Padavinske razmere so ocenjene na podlagi statistične in prostorske analize, opravljene v programskih orodjih ArcGIS Desktop in STATISTICA. Največ statistično značilnih korelacij, ki nakazujejo linearni trend v skupni količini padavin, je bilo odkritih za mesec marec. Najmanjša mesečna skupna količina padavin (samo približno $6 \%$ večletnega mesečnega povprečja) je bila zabeležena oktobra 1951, najvišja (približno 355 \% večletnega mesečnega povprečja) pa oktobra 1974. Določena so tri padavinska območja na Poljskem.

KLJUČNE BESEDE: podnebne spremembe, padavinske razmere, število dni s padavinami, padavinska območja, Poljska

The paper was submitted for publication on August $3^{\text {rd }}, 2020$.

Uredništvo je prejelo prispevek 3. avgusta 2020.

\footnotetext{
${ }^{1}$ Wrocław University of Environmental and Life Sciences, Institute of Landscape Architecture, Wrocław, Poland robert.kalbarczyk@upwr.edu.pl (https://orcid.org/0000-0002-0564-8653)

${ }^{2}$ Adam Mickiewicz University in Poznań, Faculty of Human Geography and Planning, Poznań, Poland ekalb@amu.edu.pl (https://orcid.org/0000-0002-4871-2483)
} 


\section{Introduction}

Despite many years of research on climate change, there are no clear indications as to the direction and intensification of precipitation variability. The scenarios and models presented in the literature all assume a global, albeit varied, increase in air temperature. On the other hand, research results on the direction and range of precipitation $(\mathrm{Pr})$ variability in the future (including in Poland) remain burdened with much higher uncertainty (Kundzewicz and Kozyra 2011; IPCC 2014; Kalbarczyk et al. 2018).

Analyses of historical data that contains precipitation totals and the number of days with precipitation or extreme precipitation values indicate that in the $20^{\text {th }}$ century and at the turn of the $21^{\text {st }}$ century there were no clear regularities in their patterns (Halimatou, Kalifa and Kyei-Baffour 2017; Pathak et al. 2018; Caloiero, Caloiero and Frustaci 2018). Many reports frequently point to the lack of a significant trend of precipitation totals in Europe; however, regional occurrences of both positive and negative Pr trends have been reported (Kundzewicz, Radziejewski and Pińskwar 2006; Labudová, Faško and Ivaňáková 2015; Łupikasza 2017). Also, previous research on the multi-year variability of Pr conducted for various regions of Poland did not produce any unambiguous results so it is not certain how it will develop in the future (Majewski, Przewoźniczuk and Kleniewska 2010; Żarski et al. 2014; Ilnicki et al. 2015; Ziernicka-Wojtaszek and Kopcińska 2020). Precipitation variability occurring in Central Europe is mostly explained by its dependence on atmospheric circulation, which determines the prevalence of continental or oceanic weather trends and shapes the global and regional climates (Degirmendžić, Kożuchowski and Żmudzka 2004; Twardosz, Niedźwiedź and Łupikasza 2011; Młyński, Cebulska and Wałęga 2018). Out of the remaining factors shaping precipitation variability in Poland research studies included e.g. the importance of cloud cover and terrain (Bokwa and Skowera 2008; Żmudzka 2009). Knowledge of precipitation variability is vital for many sectors of the economy. The sum of precipitation and its temporal distribution affect the functioning and development of, for example, agriculture, fisheries, forestry, water transport, hydropower generation and tourism, thereby influencing the quality of life in a given country (Kalbarczyk, Kalbarczyk and Raszka 2011; Marcinkowski and Piniewski 2018; Radzka, Jankowski and Jankowska 2019). Recognizing the degree of Pr variability is essential for climate risk management (Marković et al. 2014; Šebenik, Brilly and Šraj 2017; Młyński, Cebulska and Wałęga 2018; Stefanova et al. 2019; Ziernicka-Wojtaszek and Kopcińska 2020). Floods resulting from sudden atmospheric precipitation are one of the biggest climatic threats to cities (PedrozoAcuña et al. 2017; Szewrański et al. 2018; Olsson et al. 2019), therefore determination of precipitation trends can be useful when planning adaptation measures to climate change for urban and rural areas (Hardoy et al. 2014; Reckien et al. 2015; Chu, Anguelovski and Roberts 2017). Knowledge of precipitation variability in a multi-year and spatial perspective requires continuous updating, so research studies are conducted anew for the changing climatic conditions in various regions of the world.

The aims of this paper were to determine the temporal and spatial variability of precipitation and to distinguish regions of Poland based on specific variability of precipitation totals.

\section{Materials and methods}

The paper used daily precipitation totals which were collected at 74 meteorological stations located across Poland (Figure 1). Precipitation totals ( $\mathrm{Pr}, \mathrm{mm}$ ) were calculated for each year in the analyzed period between 1951 and 2018 for each individual month in each of these years. The initial data were made accessible by the Polish Institute of Meteorology and Water Management which is responsible for systematic measurements and observations with the use of their basic network of stations and special-purpose measurement networks.

Single missing daily precipitation totals were added on the basis of complete measurement series from the nearest stations. Longer series of missing daily totals (at least 10 days long) were determined by means of linear or non-linear regression equations whose calculated determination coefficients described at least a $64 \%$ fit of the empirical data to the regression function.

Precipitation patterns were described with the following indices: the mean $(\overline{\mathrm{x}})$, standard deviation (SD), variation coefficient $(\mathrm{V})$, and extreme values, i.e. the minimum (MIN) and the maximum (MAX) calculated on the basis of all the analyzed annual periods and months during the entire analyzed 1951-2018 period (further accepted also as the norm). Spearman's coefficient (r) was used to describe the linear precipitation trend. Precipitation conditions for chosen 2 years and the 24 months with the lowest and highest 


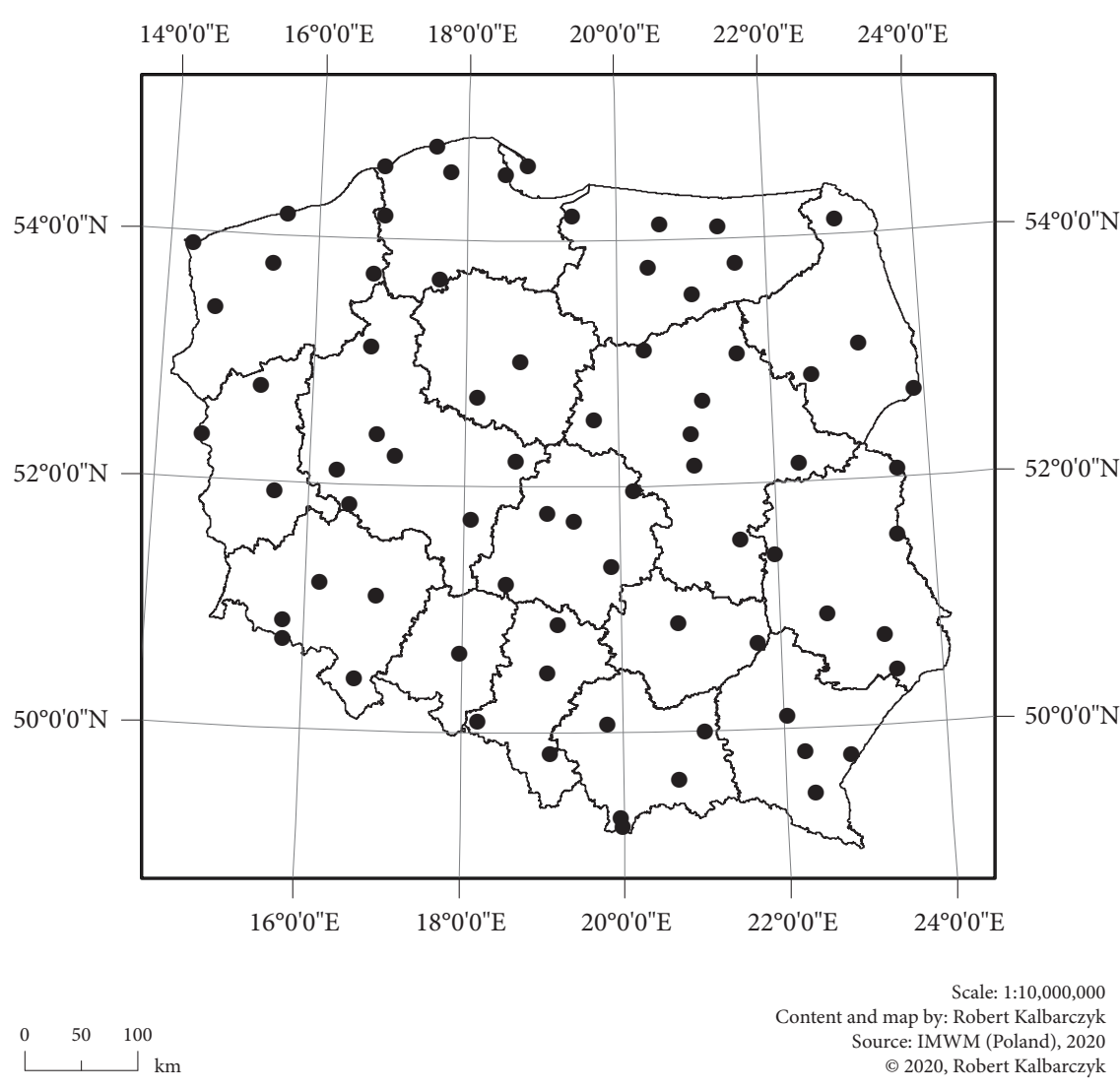

Figure 1: Locations of meteorological stations used in the research study.

precipitation totals were characterized by an index that expressed extreme values as a percentage of the sum of multi-year precipitation and the average number of days without precipitation (0.0) and with precipitation in the following ranges: $0.1-1,>1,>2,>5,>10,>20$ and $>50 \mathrm{~mm}$ (Olechnowicz-Bobrowska 1970; Bochenek 2020).

Maps presenting statistical characteristics of precipitation conditions in Poland in various time functions with a borders of the 16 administrative provinces were prepared using inverse distance weighting in ArcGIS Desktop 10.6.1 software. Due to the fact that very high precipitation variability occurs in only one region of Poland, some maps were supplemented with a legend which does not use the same range of values in all intervals. Therefore, on the color scale the last two ranges of values were marked with grey and black. The legend showing the linear trend of precipitation totals gives critical values of Spearman's coefficient for $\alpha \leq 0.1$ and $\alpha \leq 0.01$, which amount to 0.201 and 0.311 , respectively.

The regions in Poland with a similar variability of precipitation were determined on the basis of hierarchical clustering in 3 multi-year periods: 1951-1984 (the first half of the entire examined multi-year period), 1985-2018 (the second half of the entire examined multi-year period), and 1951-2018 (the whole examined multi-year period). The analysis took into consideration 24 variables: average multi-year precipitation totals and their average multi-year standard deviation values, both of which were calculated separately for each month for each meteorological station and each analyzed multi-year period. Before the analysis, the values of all variables $(\mathrm{Z})$ were standardized according to the equation: 


$$
Z=\frac{\left(x_{i}-\bar{x}\right)}{S D}
$$

where $x_{i}$ is the observed value of a variable from a given station in a given month and multi-year period, $\overline{\mathrm{x}}$ is the arithmetic mean for all stations in a given month and multi-year period, and SD is the standard deviation from all stations in a given month and multi-year period.

The study used an agglomerative method of clustering to classify meteorological stations into groups so that the degree of correlation of a given station with stations from the same group would be possibly the strongest, and with stations from the remaining groups possibly the weakest. Distances between stations in multidimensional space were calculated by means of the city block distance (Manhattan distance), thanks to which the effect of outliers is reduced. Distances between new clusters were determined by Ward's method. The accepted measure of the linkage amounted to 110. The method aims to minimize the sum of the squared deviations of any two clusters which may be formed at any stage.

Regression and cluster analysis were carried out in STATISTICA 13.3 software.

\section{Results}

\subsection{Precipitation distribution}

In 1951-2018, the average precipitation total (Pr) for the whole of Poland was approximately $634 \mathrm{~mm}$ (Table 1). In some months, Pr fluctuated from approximately $31 \mathrm{~mm}$ in February to approximately $90 \mathrm{~mm}$ in July. Pr of up to $40 \mathrm{~mm}$ was also recorded in January and March, and Pr of over $70 \mathrm{~mm}$ was recorded in June and August. The annual standard deviation for multi-year precipitation totals amounted to $\sim 82 \mathrm{~mm}$, but in February it was only $\sim 13 \mathrm{~mm}$, and in July as much as $34 \mathrm{~mm}$. A high standard deviation of Pr, i.e. $>25 \mathrm{~mm}$, was calculated for August and October. The highest variability of precipitation, expressed by variation coefficient $\mathrm{V}$, was characteristic of precipitation in October (60.5\%), and the lowest - precipitation in June (27.3\%), with the variability of annual precipitation sums at a level of $13 \%$. A significant positive increase in Pr for the whole country was found only for March ( $r=0.25, a \leq 0.05)$.

In Poland, the spatial distribution of average multi-year precipitation totals was very varied (Figure 2). The lowest Pr was observed in the central strip of Poland and amounted to $<550 \mathrm{~mm}$.

Precipitation increased latitudinally northwards and southwards, where the observed totals were the highest, namely $>1300 \mathrm{~mm}$. In some months, the spatial structure of Pr was slightly different than for the entire year (Figure 3).

Table 1: Characteristics of precipitation totals variability in Poland, 1951-2018.

\begin{tabular}{|c|c|c|c|}
\hline \multirow[b]{2}{*}{ Period / month } & \multicolumn{3}{|c|}{ Characteristics } \\
\hline & $\bar{x} \pm S D$ & r & V \\
\hline January-December & $634.1 \pm 82.3$ & $0.17^{\mathrm{ns}}$ & 13.0 \\
\hline January & $36.3 \pm 15.0$ & $0.15^{\mathrm{ns}}$ & 41.3 \\
\hline February & $31.3 \pm 13.1$ & $0.04^{\mathrm{ns}}$ & 41.9 \\
\hline March & $35.4 \pm 13.5$ & $0.25^{1}$ & 38.1 \\
\hline April & $41.0 \pm 14.4$ & $-0.11^{\mathrm{ns}}$ & 35.1 \\
\hline May & $62.5 \pm 20.3$ & $0.03^{\text {ns }}$ & 32.5 \\
\hline June & $75.8 \pm 20.7$ & $-0.07^{\text {ns }}$ & 27.3 \\
\hline July & $89.6 \pm 34.0$ & $0.05^{\text {ns }}$ & 37.9 \\
\hline Auqust & $72.0 \pm 25.1$ & $-0.09^{\text {ns }}$ & 34.8 \\
\hline September & $56.3 \pm 23.7$ & $0.11^{\text {ns }}$ & 42.1 \\
\hline October & $46.1 \pm 27.9$ & $0.13^{\mathrm{ns}}$ & 60.5 \\
\hline November & $44.9 \pm 16.4$ & $0.01^{1 \mathrm{~ns}}$ & 36.5 \\
\hline December & $42.7 \pm 16.3$ & $0.04^{\mathrm{ns}}$ & 38.2 \\
\hline
\end{tabular}

Notes: $\bar{x}$ - arithmetic mean (mm), SD - standard deviation $(\mathrm{mm}), \mathrm{r}$ - Spearman's correlation coefficient for a linear trend, $V$ - coefficient of variation (\%), ${ }^{1}$ significant at $a \leq 0.05,{ }^{\text {, }}$ - non-significant at $a \geq 0.1$ 

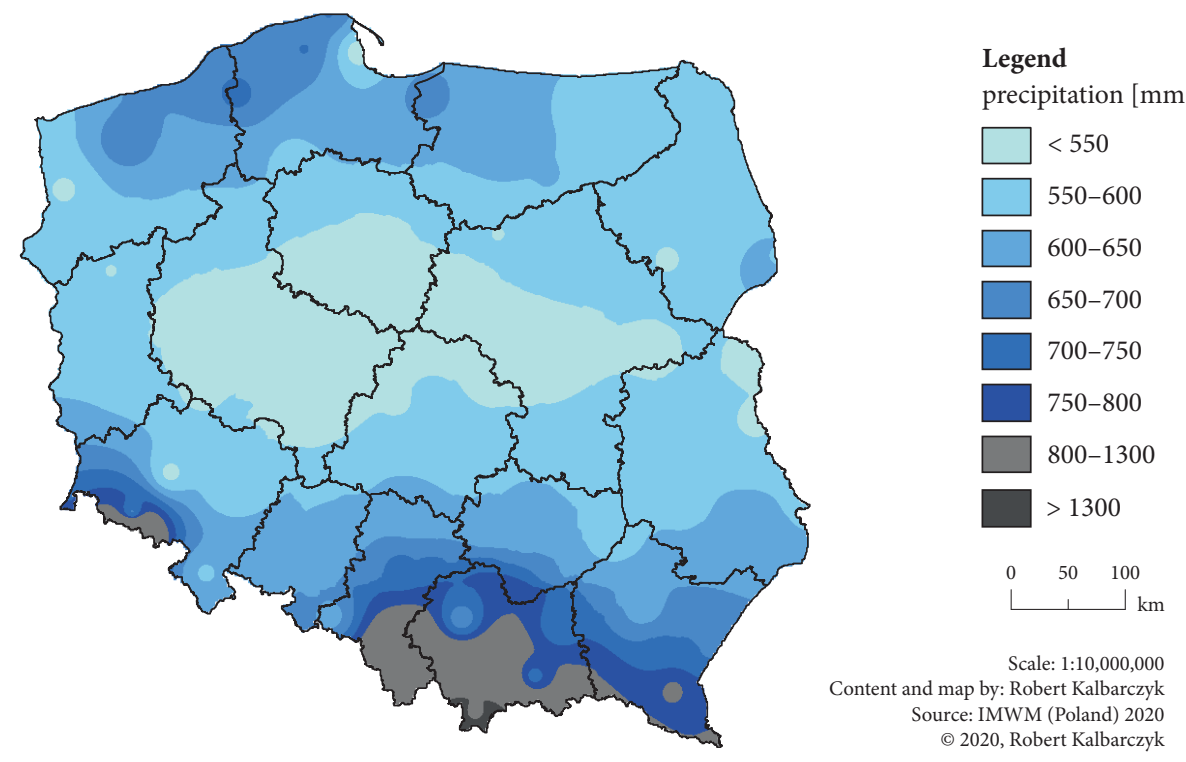

Figure 2: Spatial distribution of average multi-year annual precipitation totals in Poland, 1951-2018.

Figure 3: Spatial distribution of average multi-year precipitation [mm] totals by months in Poland, 1951-2018. p. 48-49

From January to March, the lowest value of precipitation $(<30 \mathrm{~mm})$ occurred mainly in central-east Poland; the highest, i.e. $>80-90 \mathrm{~mm}$, occurred in the southern part of the country. From April to June, the lowest $\operatorname{Pr}$ was observed in the Polish Plains (from $<40 \mathrm{~mm}$ in April to $<60 \mathrm{~mm}$ in May), and the highest was in the south (from $>105 \mathrm{~mm}$ in April to $>170 \mathrm{~mm}$ in June). In July, Pr oscillated from $<80 \mathrm{~mm}$ to $>180 \mathrm{~mm}$, with the lowest values in the central-west and central-east parts; in August Pr oscillated from $<60$ to $>150 \mathrm{~mm}$, with the lowest values in central-west Poland; in September Pr oscillated from $<50$ to $>110 \mathrm{~mm}$, with the lowest values in the central-west part. In October in the central strip of Poland, which stretches horizontally, precipitation amounted to $<40 \mathrm{~mm}$; in the north and south it amounted to $>85 \mathrm{~mm}$. Finally, in November and December, a Pr of $<40 \mathrm{~mm}$ occurred in central-east Poland, and a Pr of $>90-95 \mathrm{~mm}$ occurred in the south.

\subsection{Variability and precipitation trend}

In 1951-2018, the annual standard deviation of Pr for whole of Poland fluctuated from $<100$ to $>210 \mathrm{~mm}$ (Figure 4).

In the areas with the highest annual precipitation totals, the calculated standard deviation values (SD) were also the highest. In particular months, the standard deviation of Pr oscillated from $<15 \mathrm{~mm}$ in January to $>90 \mathrm{~mm}$ in July (Figure 5).

\section{Figure 5: Spatial distribution of the standard deviation for monthly precipitation [mm] totals in Poland, 1951-2018. p. 50-51}

The lowest SD was calculated for precipitation in 3 months: January, in some stations located in central Poland; February, in north-east and central Poland; March, in central Poland. The highest SD in all months was calculated for precipitation in the southern part of the country, i.e. in high-mountain areas, and also in October in the northern part of Poland. In the analyzed multi-year period, annual precipitation totals clearly decreased or increased only in some parts of Poland (Figure 6). 


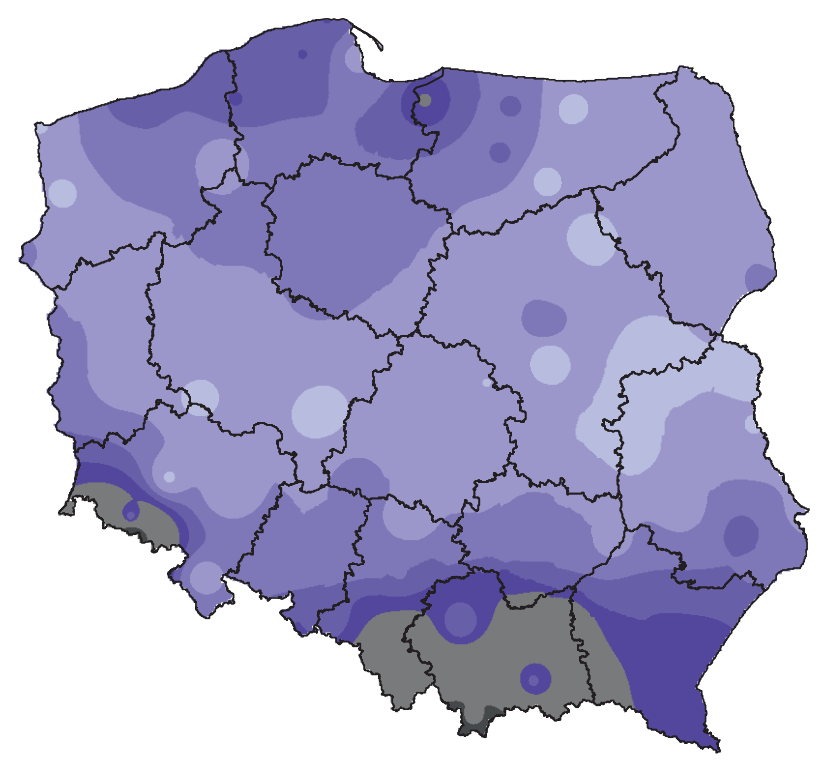

Legend

percipitation [mm]

$\square<100$

$\square$ 100-110

$\square$ 110-120

ए 120-130

130-140

140-210

$>210 \mathrm{~mm}$

$\begin{array}{lll}0 & 50 \quad 100\end{array}$ $\mathrm{km}$

Scale: $1: 10,000,000$ Content and map by: Robert Kalbarczyk Source: IMWM (Poland), 2020 (C) 2020, Robert Kalbarczyk

Figure 4: Spatial distribution of the standard deviation for annual precipitation totals in Poland, 1951-2018.

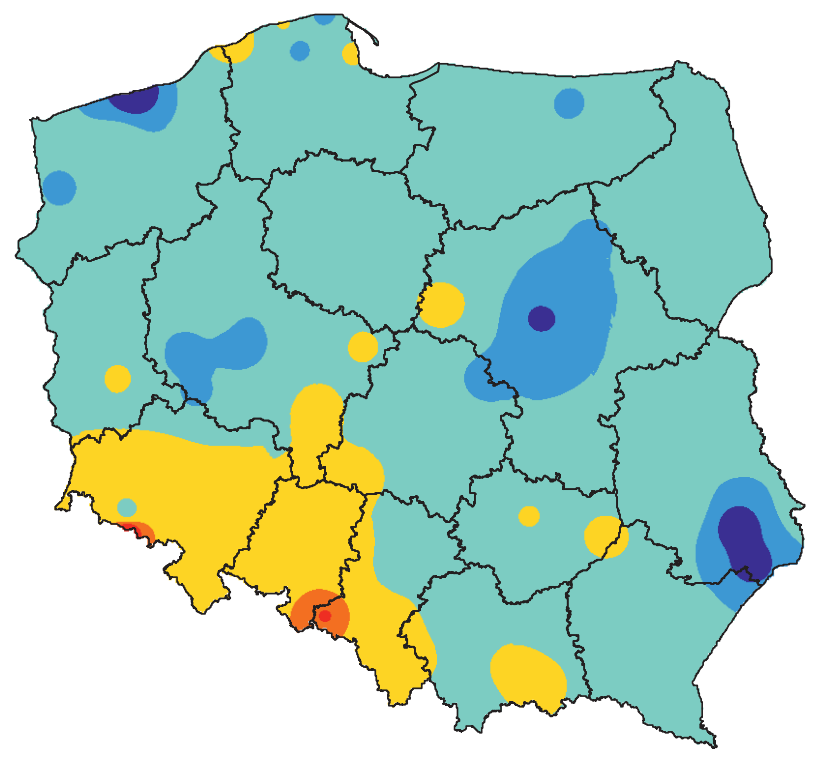

Legend

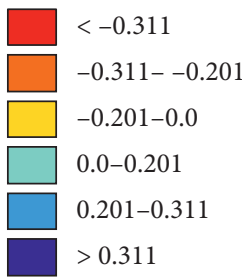

$\begin{array}{lll}0 & 50 & 100\end{array}$

$\mathrm{km}$

Scale: $1: 10,000,000$ Content and map by: Robert Kalbarczyk Source: IMWM (Poland), 2020 (c) 2020, Robert Kalbarczyk

Figure 6: Spatial distribution of the Spearman correlation coefficient of the linear trend for annual precipitation totals in Poland, 1951-2018. 
Robert Kalbarczyk, Eliza Kalbarczyk, Precipitation variability, trends and regions in Poland: Temporal and spatial ...
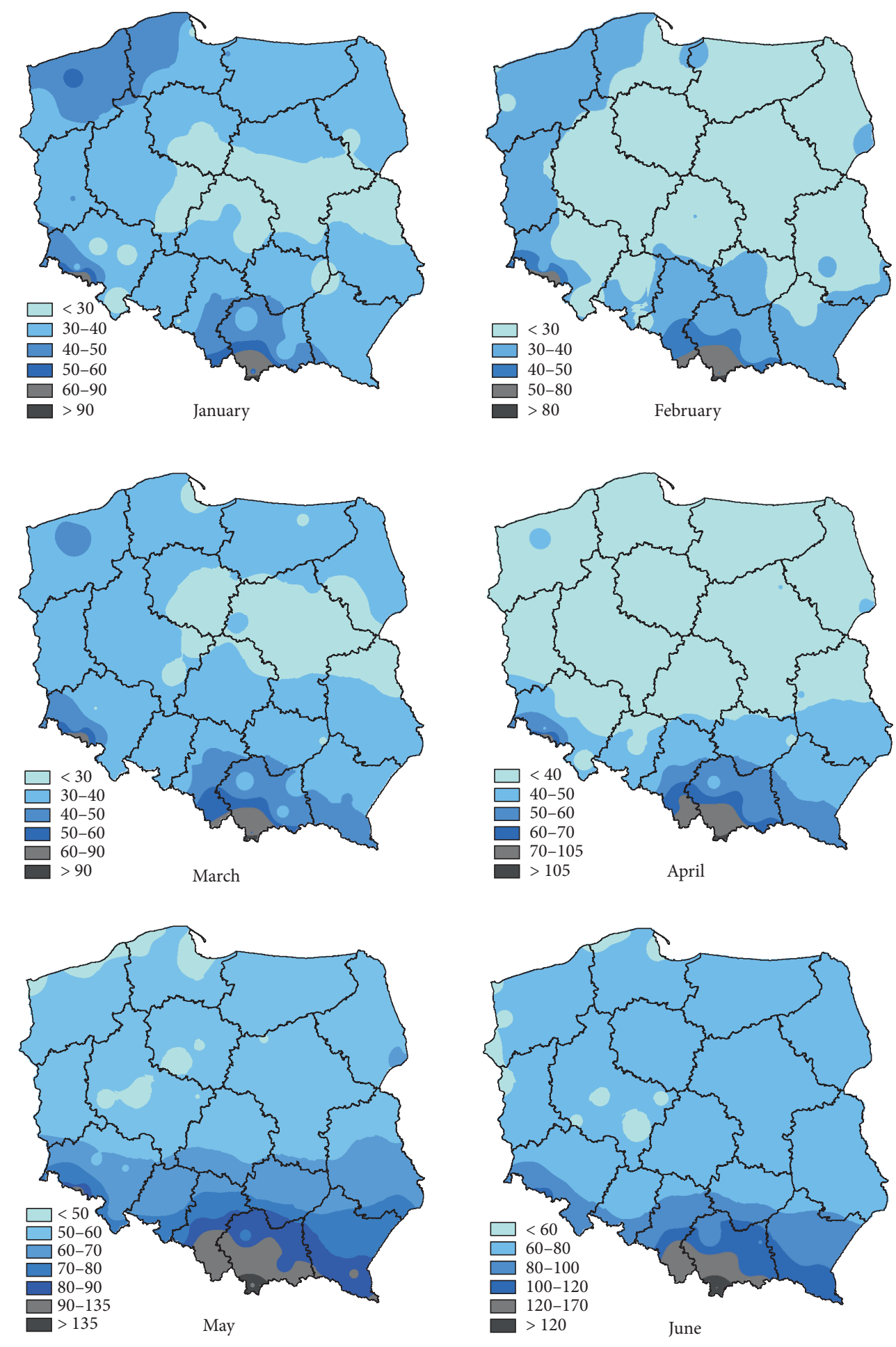

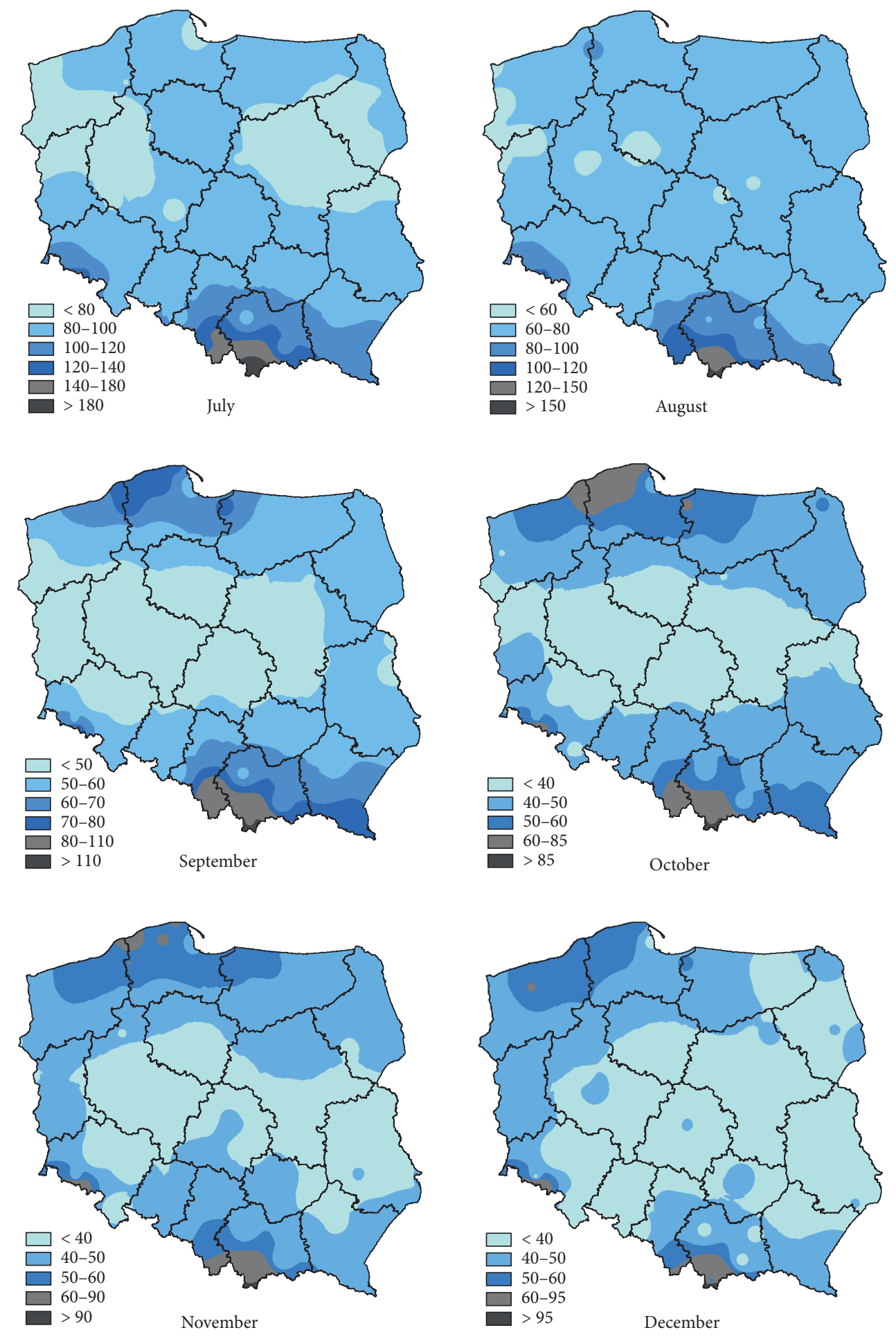
Robert Kalbarczyk, Eliza Kalbarczyk, Precipitation variability, trends and regions in Poland: Temporal and spatial...
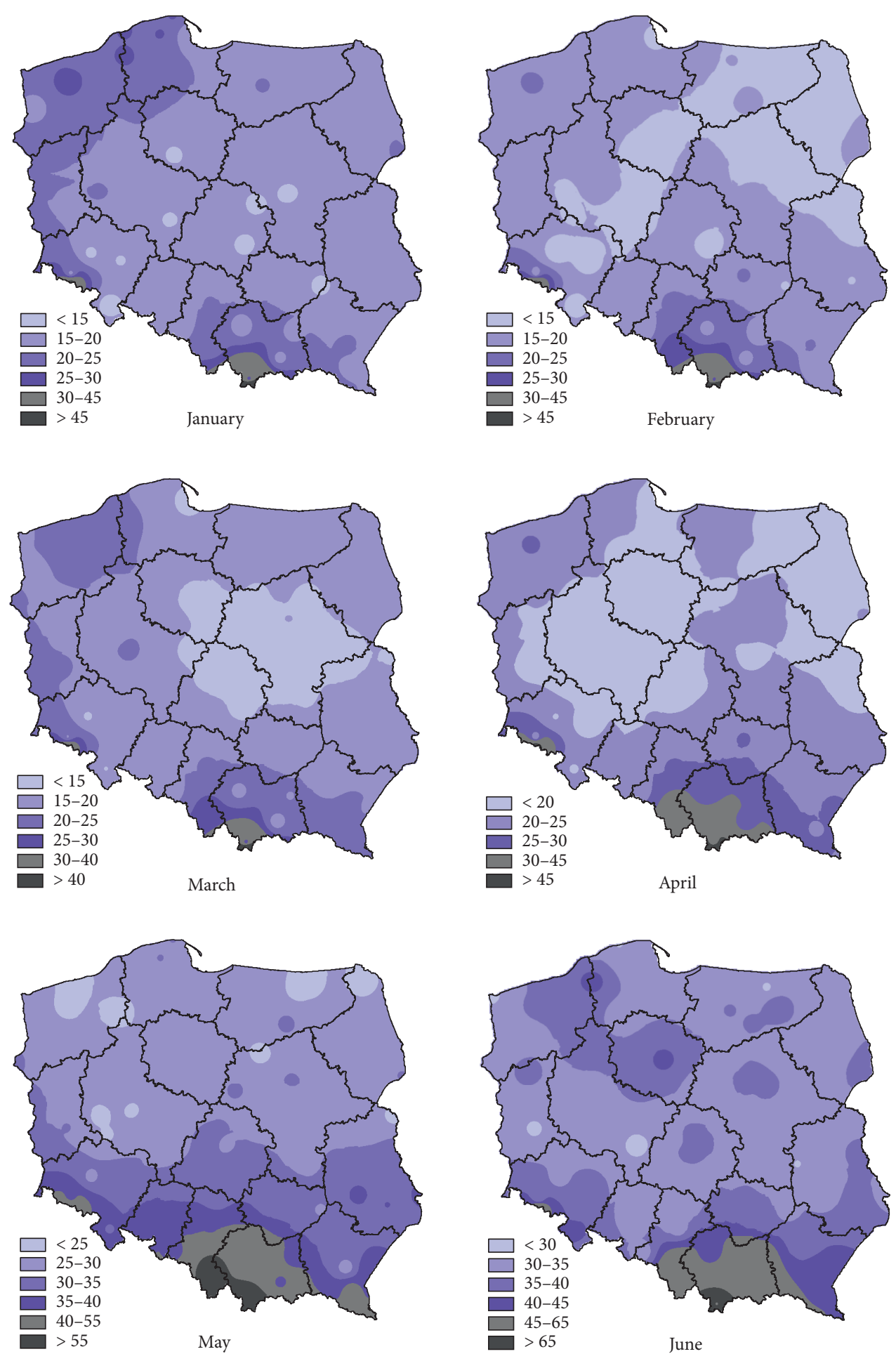

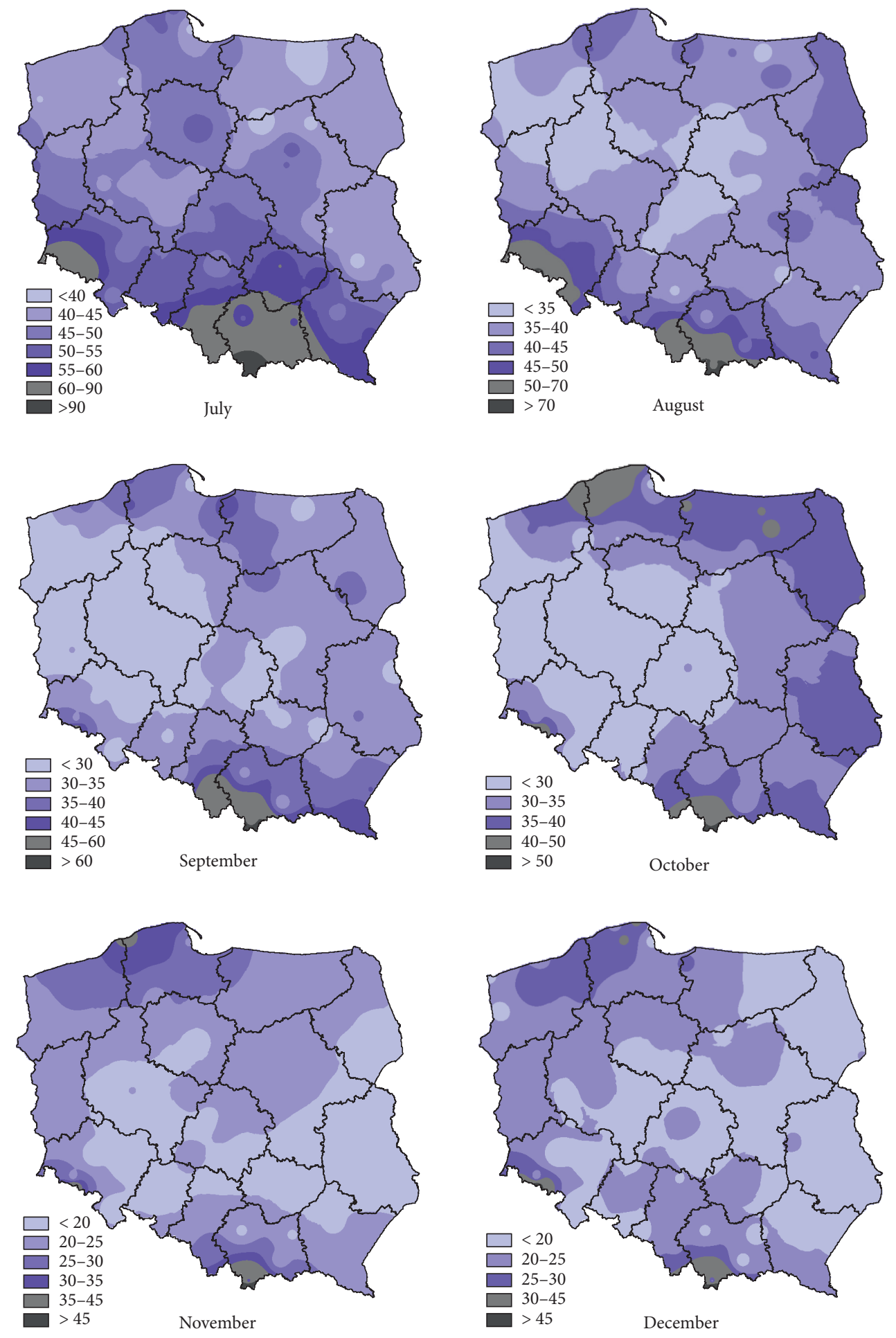
Robert Kalbarczyk, Eliza Kalbarczyk, Precipitation variability, trends and regions in Poland: Temporal and spatial...
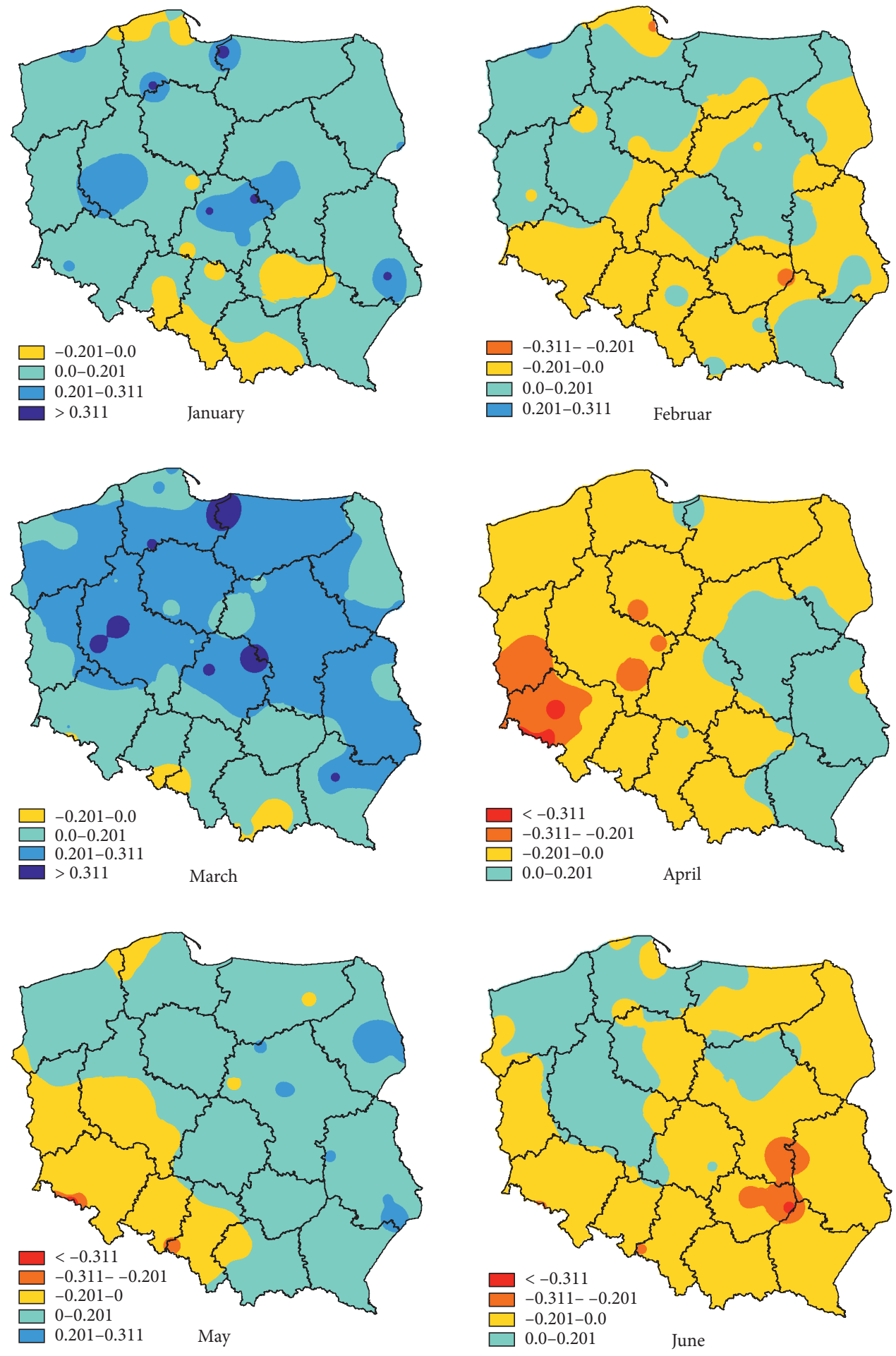

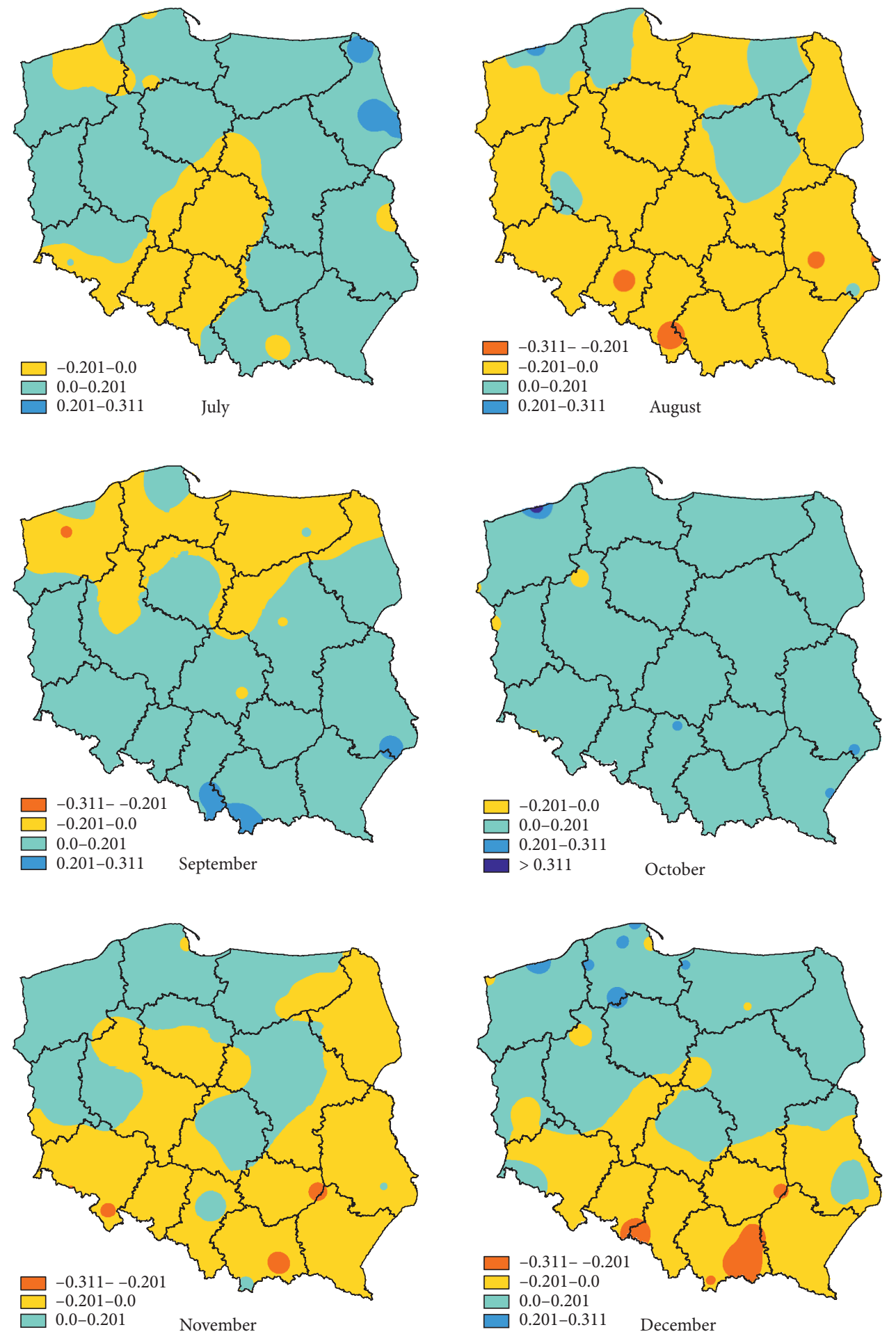
Robert Kalbarczyk, Eliza Kalbarczyk, Precipitation variability, trends and regions in Poland: Temporal and spatial...

A significant (at least at a level of $\alpha \leq 0.1$ ) positive Spearman's coefficient of $\geq 0.201$ that was calculated for Pr was found, for example, in Masovia region (central-east), Roztocze region (south-east) and the central part of the Slovincian Coast (north-east). A significant negative Spearman's coefficient was found in small areas of south-west Poland.

In March, a significant positive increase in Pr was found in northern and central Poland (Figure 7). An increase in Pr was found for 8 months, mainly in northern and eastern Poland: January, February, May, July, August, September, October and December. A significant decrease in Pr in 1951-2018 was proved in a small area of the country, mainly in western and southern Poland, also in 8 months: February, April, May, June, August, September, November and December.

\subsection{The lowest and highest precipitation}

The lowest and highest annual precipitation totals in the entire analyzed multi-year period were respectively recorded in 1982 and 2010, amounting to approximately 454 and $852 \mathrm{~mm}$ (Figure 8).

In subsequent months of the year (Figure 9), the highest Pr values in some months occurred in different years than the lowest totals. The lowest annual precipitation total in Poland, which was recorded in 1982, constituted $\sim 72 \%$ of the multi-year precipitation average (Table 2 ).

In that dry year, precipitation was not recorded on $\sim 233$ days. For $\sim 53$ days, Pr values were within a range of $0.1-1 \mathrm{~mm}$, and for $\sim 79$ days they were $>1 \mathrm{~mm}$. In 1982, the average number of days with precipitation of $>5,>10,>20$ and $>50 \mathrm{~mm}$ amounted to $27.9,10.0,2.4$ and 0.1 days, respectively. In some months,

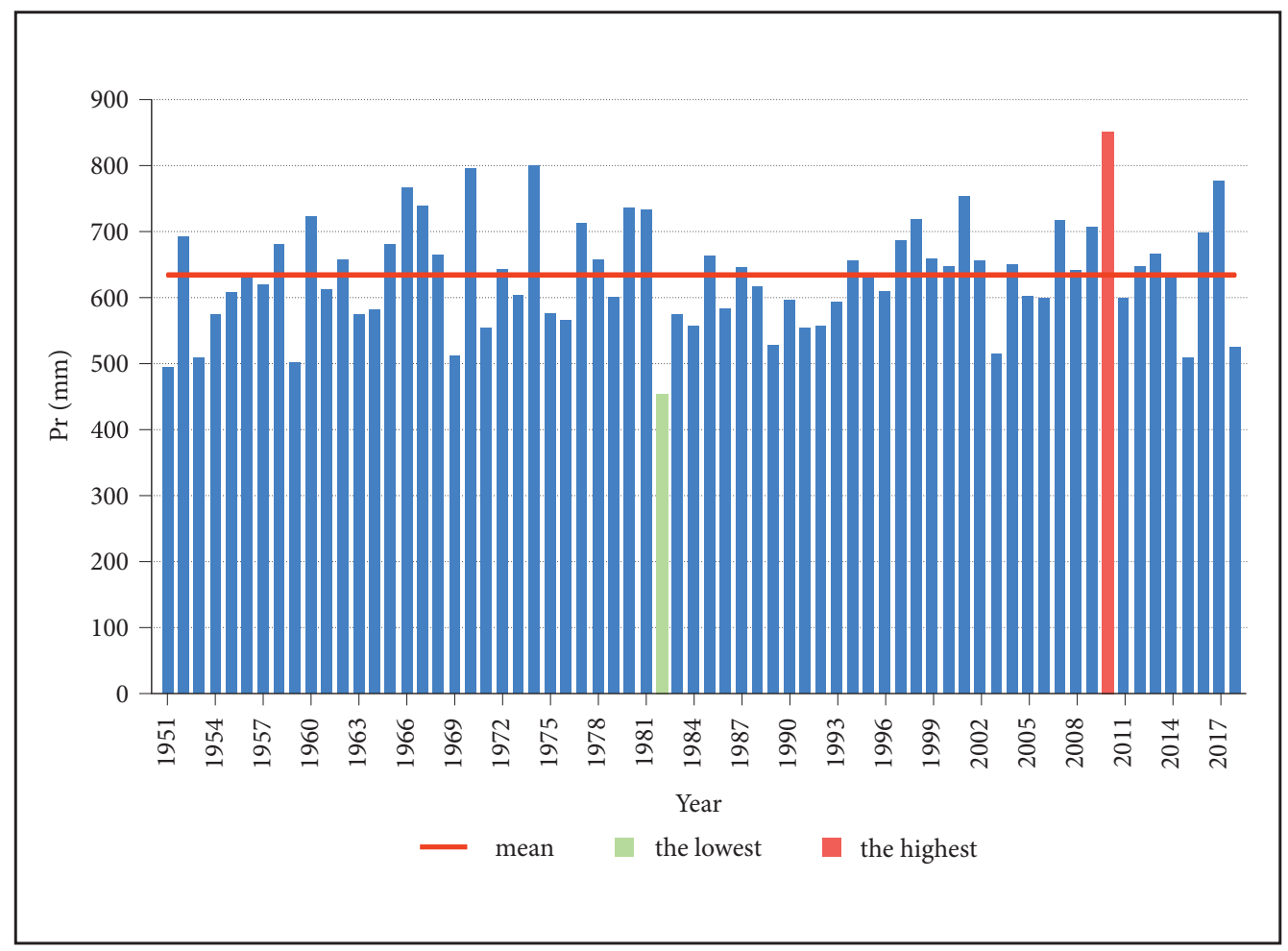

Figure 8: Temporal distribution of annual (January-December) precipitation totals in Poland, 1951-2018. 
Acta geographica Slovenica, 61-2, 2021

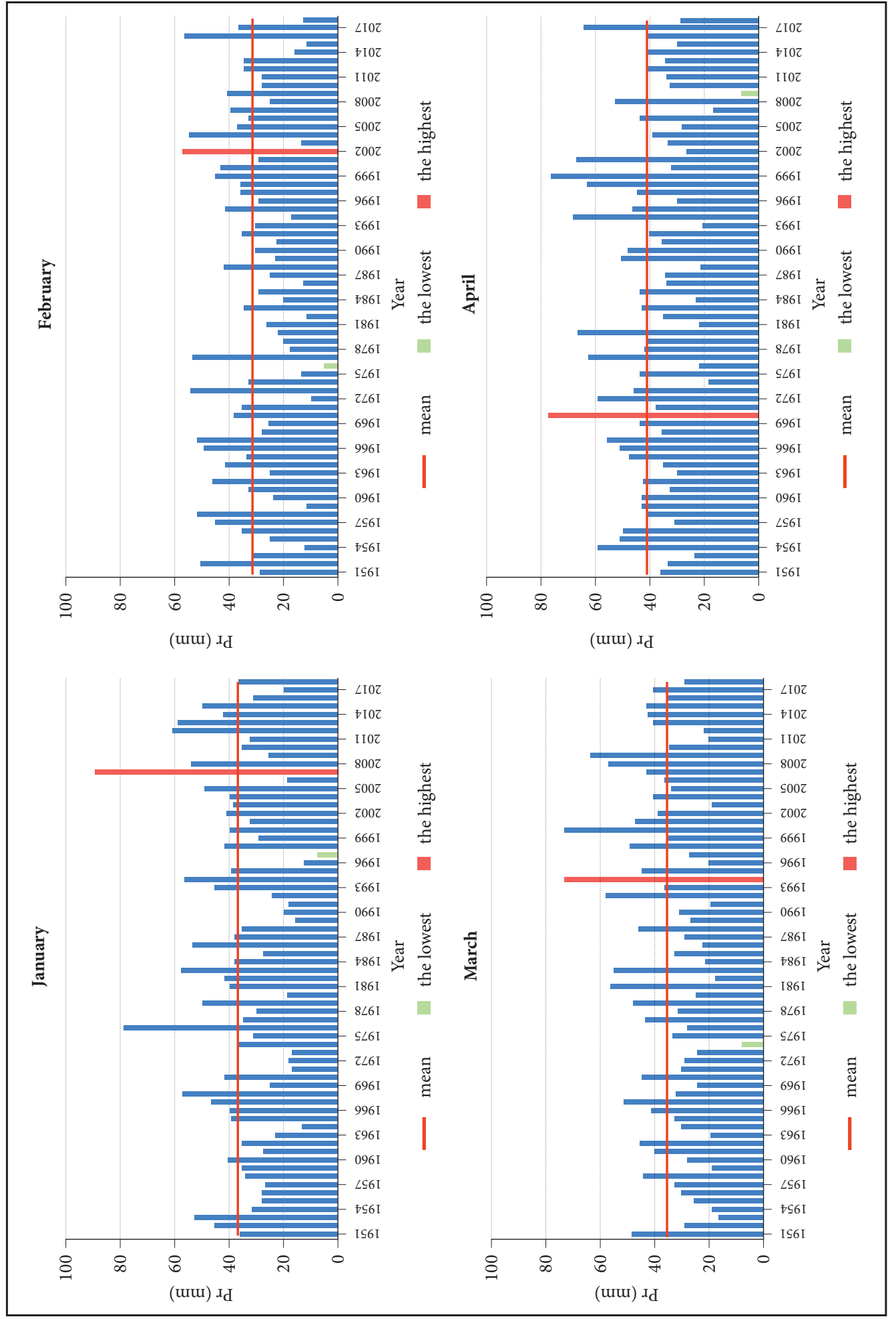


Robert Kalbarczyk, Eliza Kalbarczyk, Precipitation variability, trends and regions in Poland: Temporal and spatial...

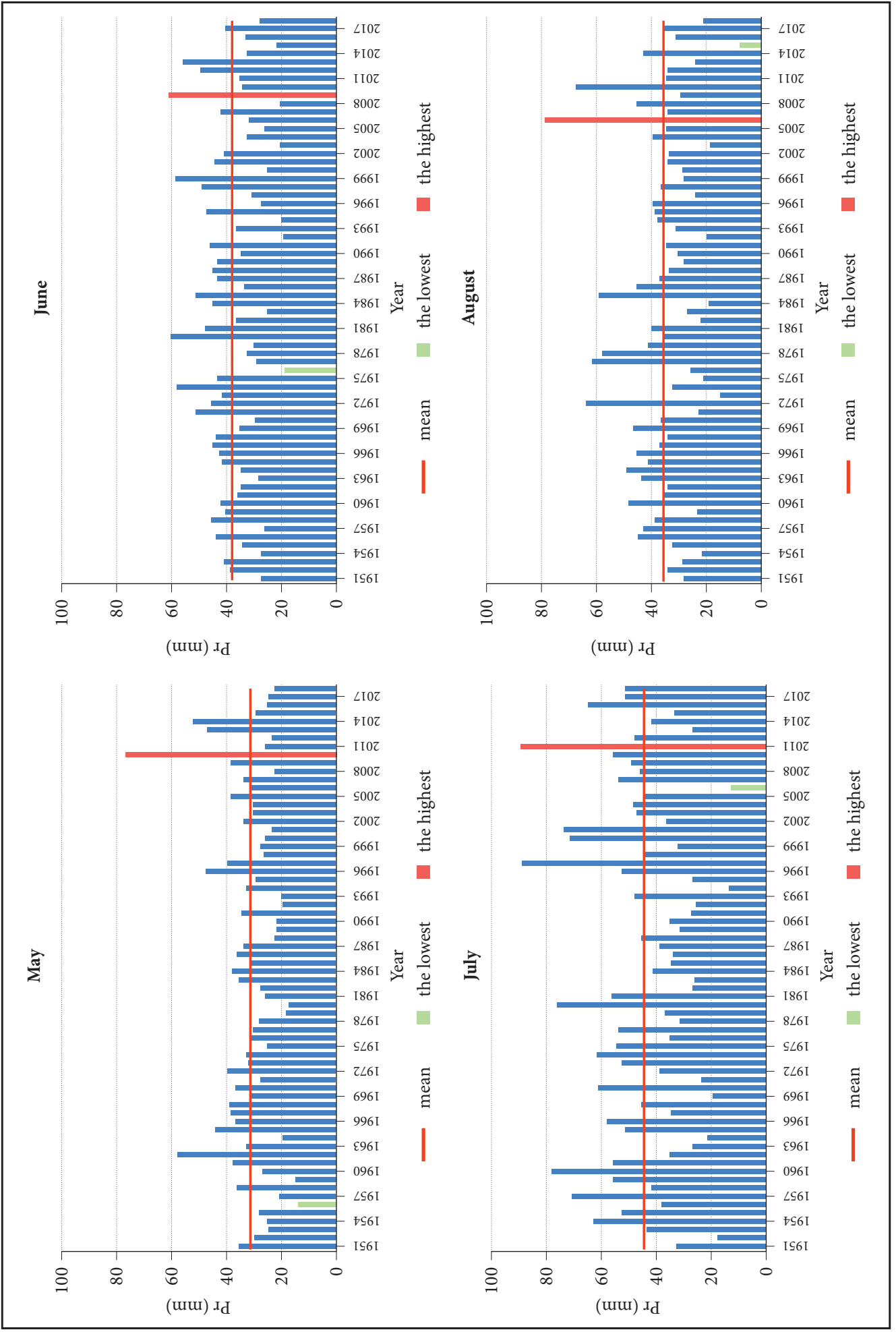


Acta geographica Slovenica, 61-2, 2021

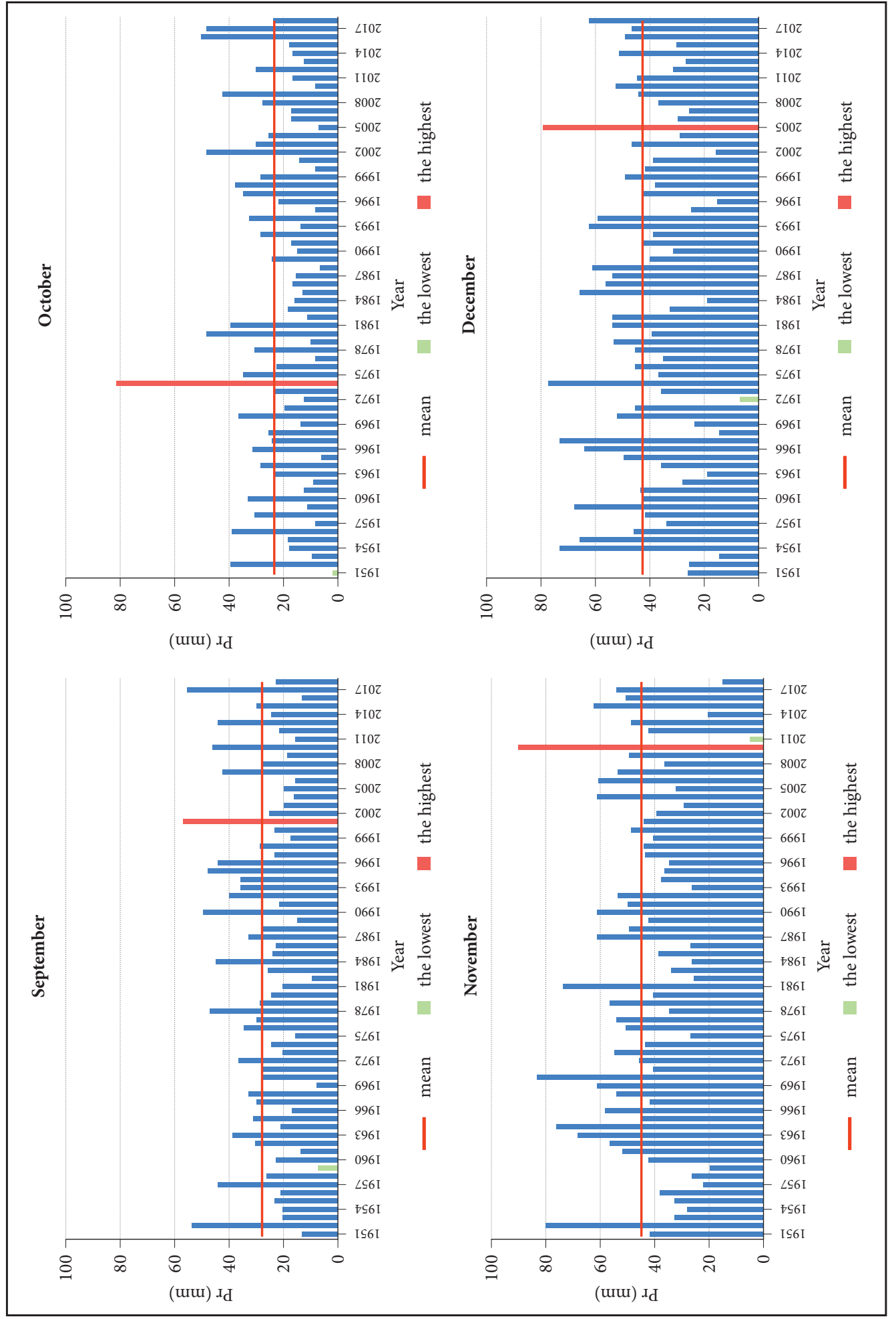


Pr constituted only about $6 \%$ of the norm in October (in 1951) to about 51\% of the norm in June (1976). In the months of the lowest $\mathrm{Pr}$, the average number of days without precipitation fluctuated from 22 days in June (1976) to 29 days in October (1951). The average number of days with precipitation within a range of 0.1-1 mm oscillated from 1.2 days in October (1951) to 6.6 days in January (1997). On the other hand, the average number of days with precipitation of $>1 \mathrm{~mm}$ fluctuated from 0.8 days in October (1951) to 5.6 days in June (1976); the average number of days with precipitation of $>2 \mathrm{~mm}$ varied from 0.3 to 4.7 days in October (1951) and June (1976), respectively. Higher Pr values, i.e. $>5 \mathrm{~mm}$, in dry months were observed much more rarely as the average number of days with such precipitation oscillated between 0.1 and 2.8 days.

The spatial distribution of the lowest annual and monthly precipitation totals in Poland is presented in Figures 10 and 11. In 1982, the totals fluctuated from $<400 \mathrm{~mm}$ in central-west and central-east Poland to $>1200 \mathrm{~mm}$ in the south (Figure 10). The lowest $\operatorname{Pr}$ values, which were recorded in 1982, were on average $150 \mathrm{~mm}$ lower than in the multi-year period of 1951-2018 (Figure 2). In particular dry months, $\operatorname{Pr}$ values oscillated from $<5 \mathrm{~mm}$ to $>105 \mathrm{~mm}$ (Figure 11).

Depending on the month, precipitation of $<5 \mathrm{~mm}$ was recorded mainly in the cold half of the year in various parts of Poland, namely in the strip stretching from the north-west to the central-east (January 1997), in the east (February 1976), in the south-east (March 1974), in the central strip stretching from the north to the south (April 2009), in most of the country (October 1951), in the south and the central strip situated along the west-east axis (November (2011) and mainly in central-east Poland (December 1972).

On the other hand, Pr of $>105 \mathrm{~mm}$ occurred in May (1956) and June (1976) in the south of Poland. In other dry months, the highest Pr was recorded in different parts of Poland, e.g. $>15 \mathrm{~mm}$ in February (1976) in central-west Poland, $>25 \mathrm{~mm}$ in April (2009) in the south-east, $>60 \mathrm{~mm}$ in September (1959) in the north, and $>70 \mathrm{~mm}$ in November (2011) in the north-west.

The highest annual Pr in Poland was registered in 2010 and constituted $~ 135 \%$ of the norm (Table 3).

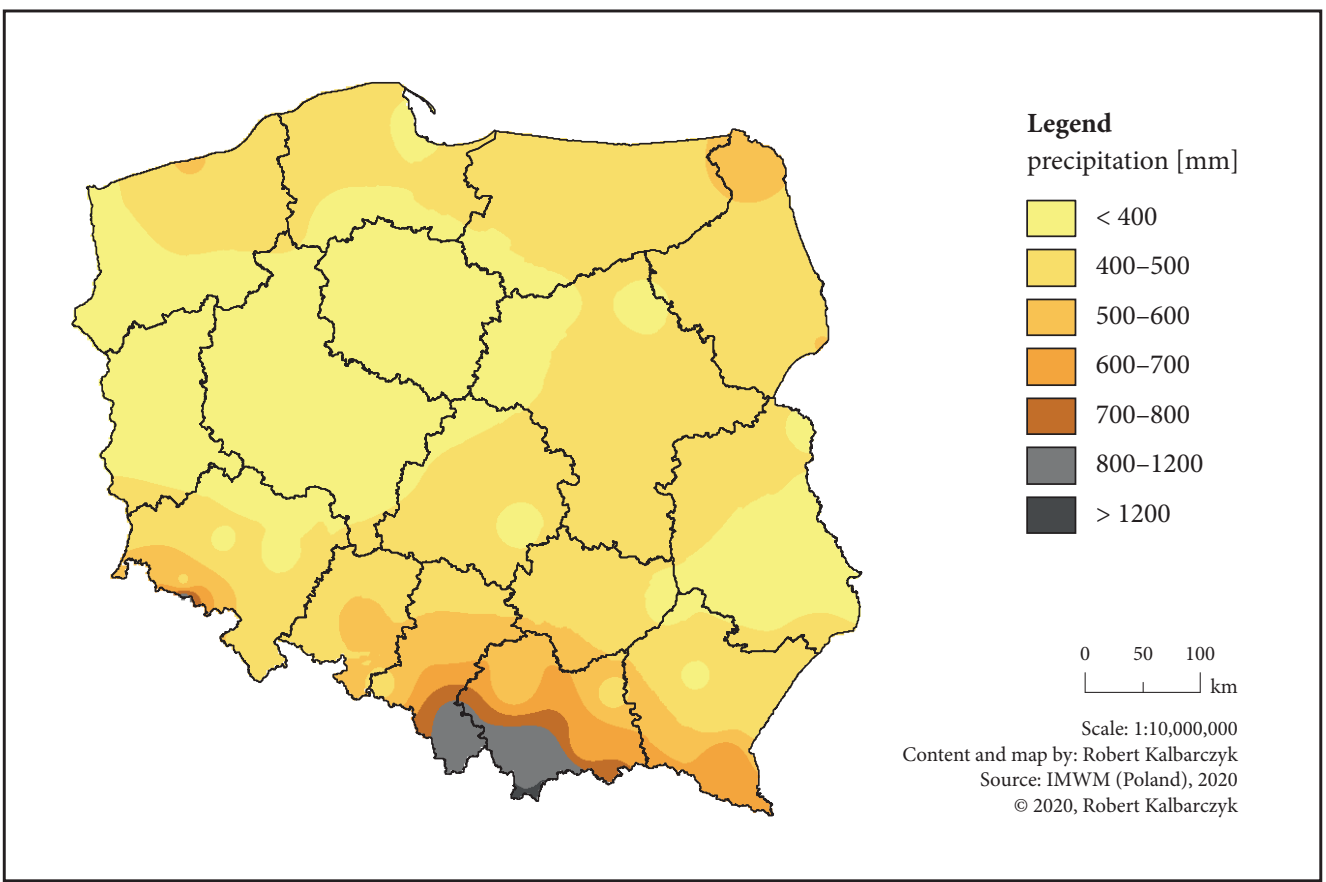

Figure 10: Spatial distribution of the lowest annual precipitation totals in Poland in all the analyzed years, 1951-2018. 


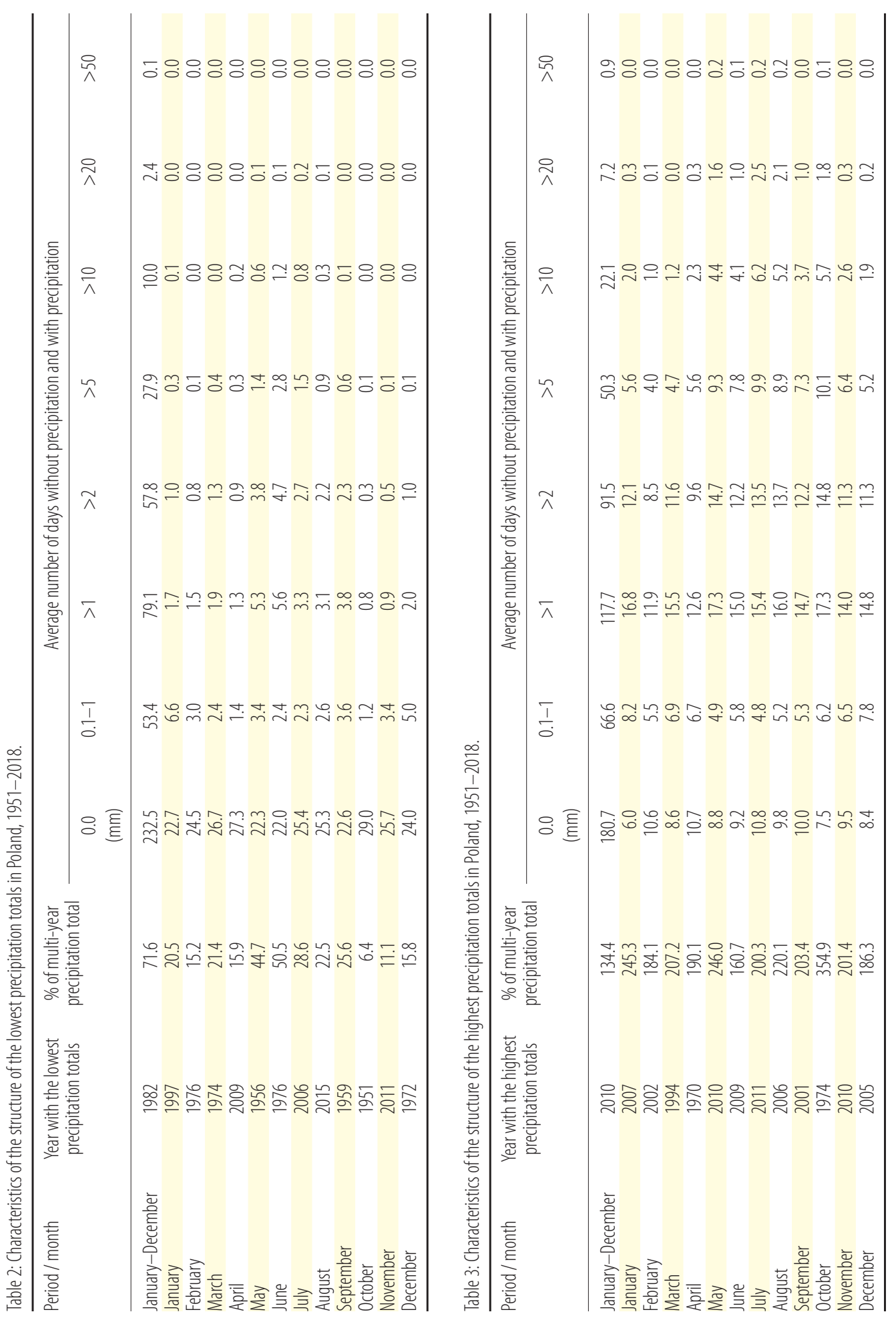


Robert Kalbarczyk, Eliza Kalbarczyk, Precipitation variability, trends and regions in Poland: Temporal and spatial...
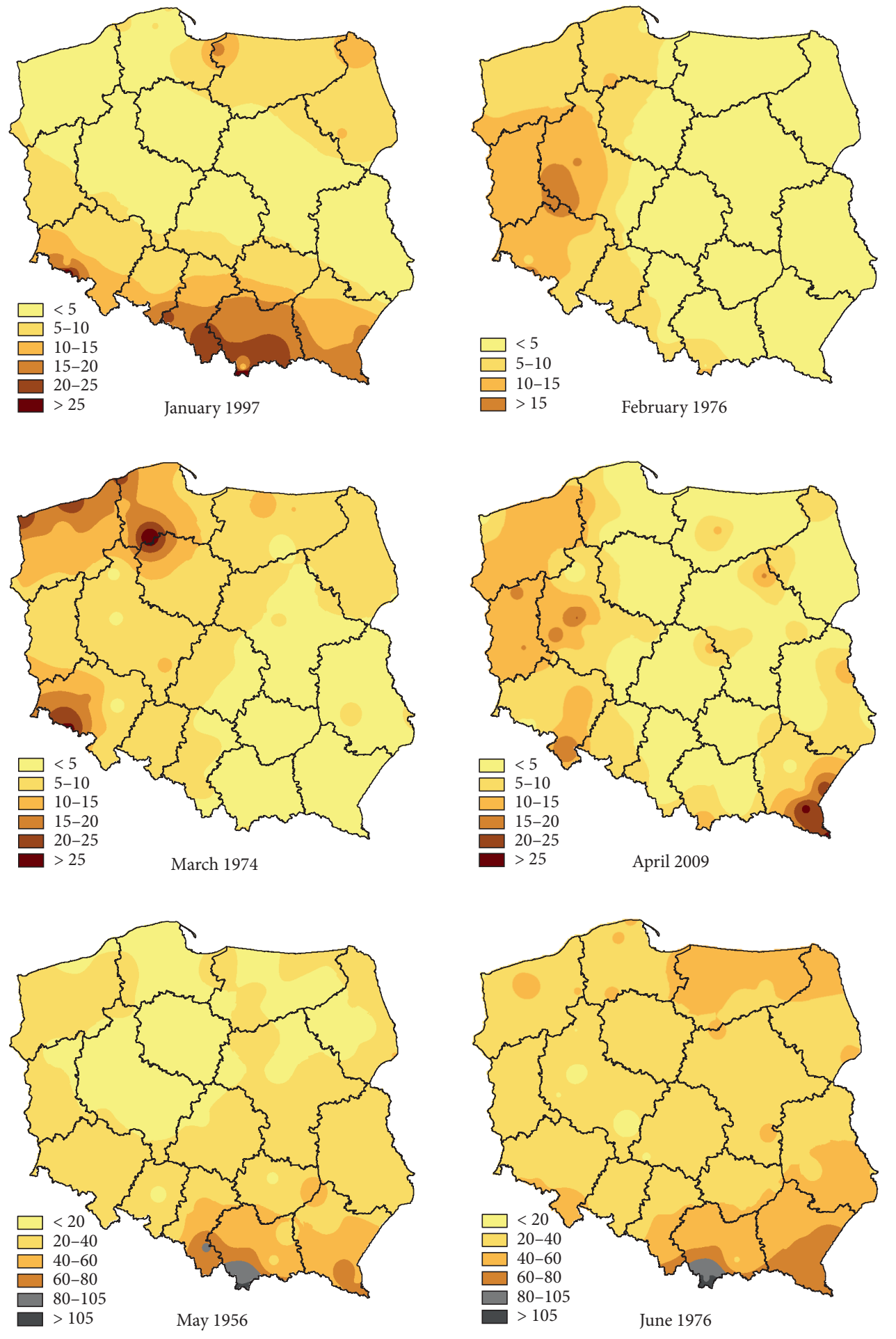


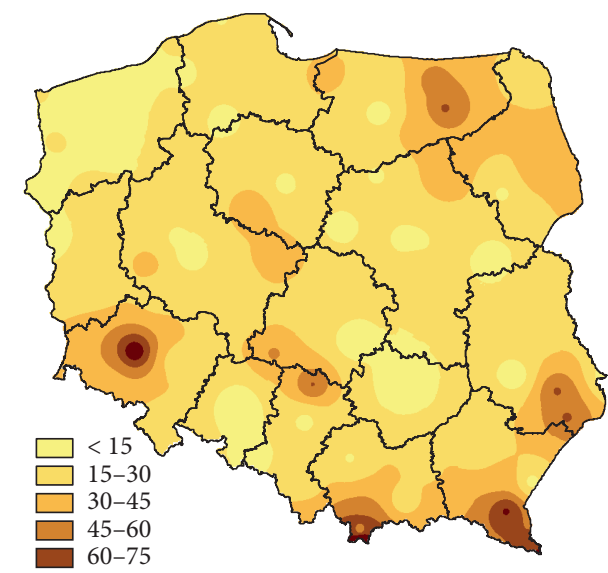

July 2006
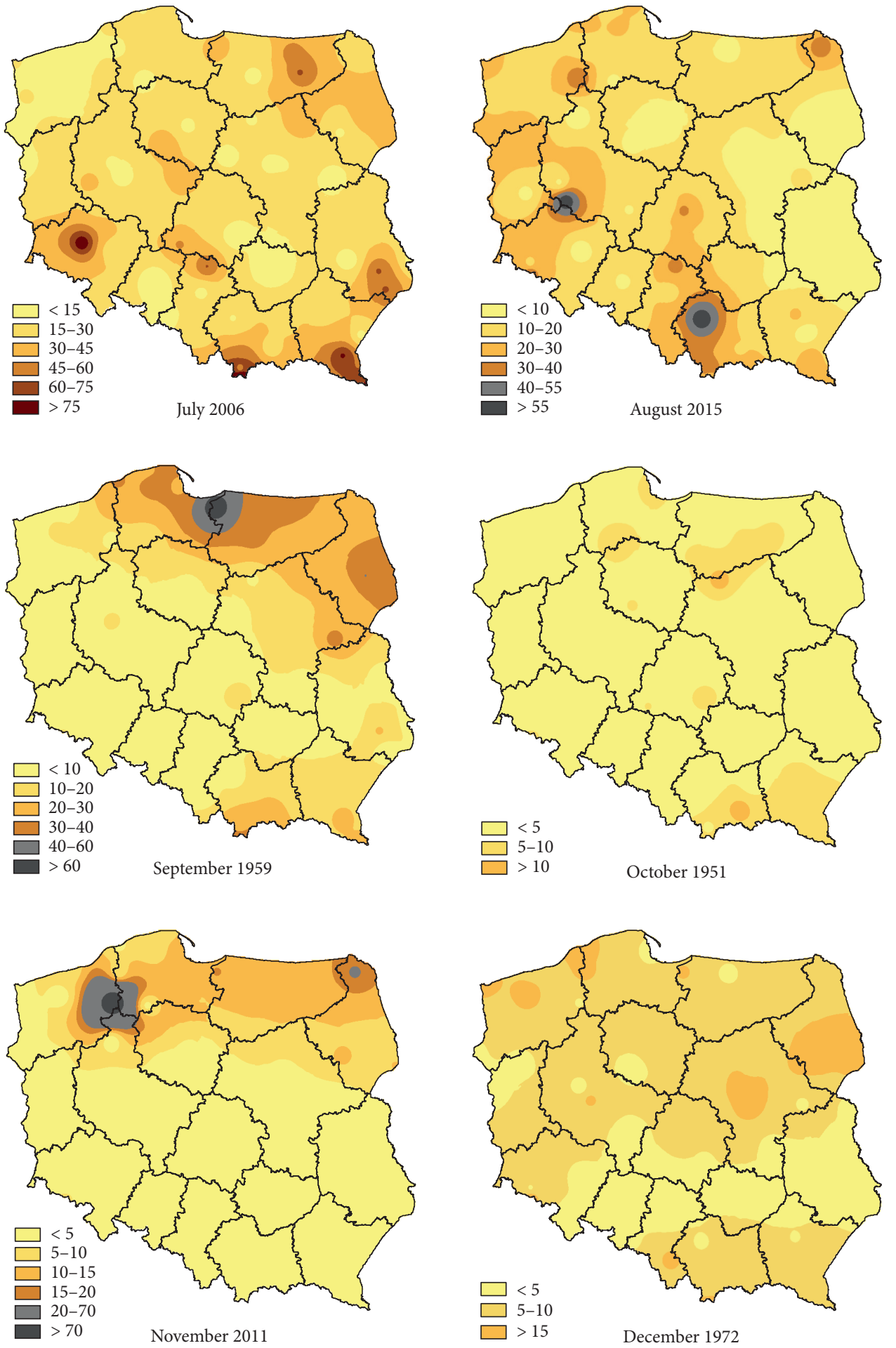
In wet 2010 year, no precipitation was registered on $\sim 181$ days. In 2010, the average number of days on which precipitation was registered in Poland was the following: $>1 \mathrm{~mm}(\sim 118$ days $),>2 \mathrm{~mm}(\sim 92$ days $)$, $>5 \mathrm{~mm}$ ( $\sim 50$ days), $>10 \mathrm{~mm}$ ( $\sim 22$ days $),>20 \mathrm{~mm}$ ( $\sim 7$ days $)$, and $>50 \mathrm{~mm}(\sim 1$ day). The highest monthly Pr ranged from about $164 \%$ of the multi-year precipitation in June (2009) to as much as approximately $355 \%$ in October (1974). In both these months, there was no rain only for 8-9 days. Precipitation of $>1 \mathrm{~mm}$ per day was observed on about 15 and 17 days in June and October, respectively: $>5 \mathrm{~mm}-$ about 8 and 10 days, $>10 \mathrm{~mm}$ - about 4 and 6 days, and $>20 \mathrm{~mm}$ - about 1 and 2 days.

In 2010, which has the highest Pr in the multi-year period, precipitation fluctuated from $<750 \mathrm{~mm}$ in the central strip and the north to $>1700 \mathrm{~mm}$ in the south of Poland (Figure 12).

The highest $\mathrm{Pr}$ in consecutive months of the year was observed in various parts of Poland, most frequently in the south (Figure 13). High precipitation values also occurred in the north (e.g. in January 2007 and October 1974), in the north-west (e.g. in February 2002 and April 1970), in the north-east (e.g. in August 2006 and October 1974) and in the east (e.g. in August 2006 and October 1974). The biggest differences in Pr occurred in May, when the totals oscillated from $<100$ to $>375 \mathrm{~mm}$, and July when the totals oscillated from $<100$ to $>320 \mathrm{~mm}$; the highest totals were recorded in the southern and eastern parts of the country.

\subsection{Precipitation regions}

In Poland, the area of each of the three regions (separated based on precipitation totals and precipitation variability) changed depending on the analyzed multi-year period (Figure 14).

In the first half of the examined multi-year period, i.e. in 1951-1984, the region with the lowest $\operatorname{Pr}$ (Cluster I) mostly covered the central-east part of Poland; the second Pr region (Cluster II) covered a bigger part of the country, namely the north, west and partly the south of Poland; the third Pr region

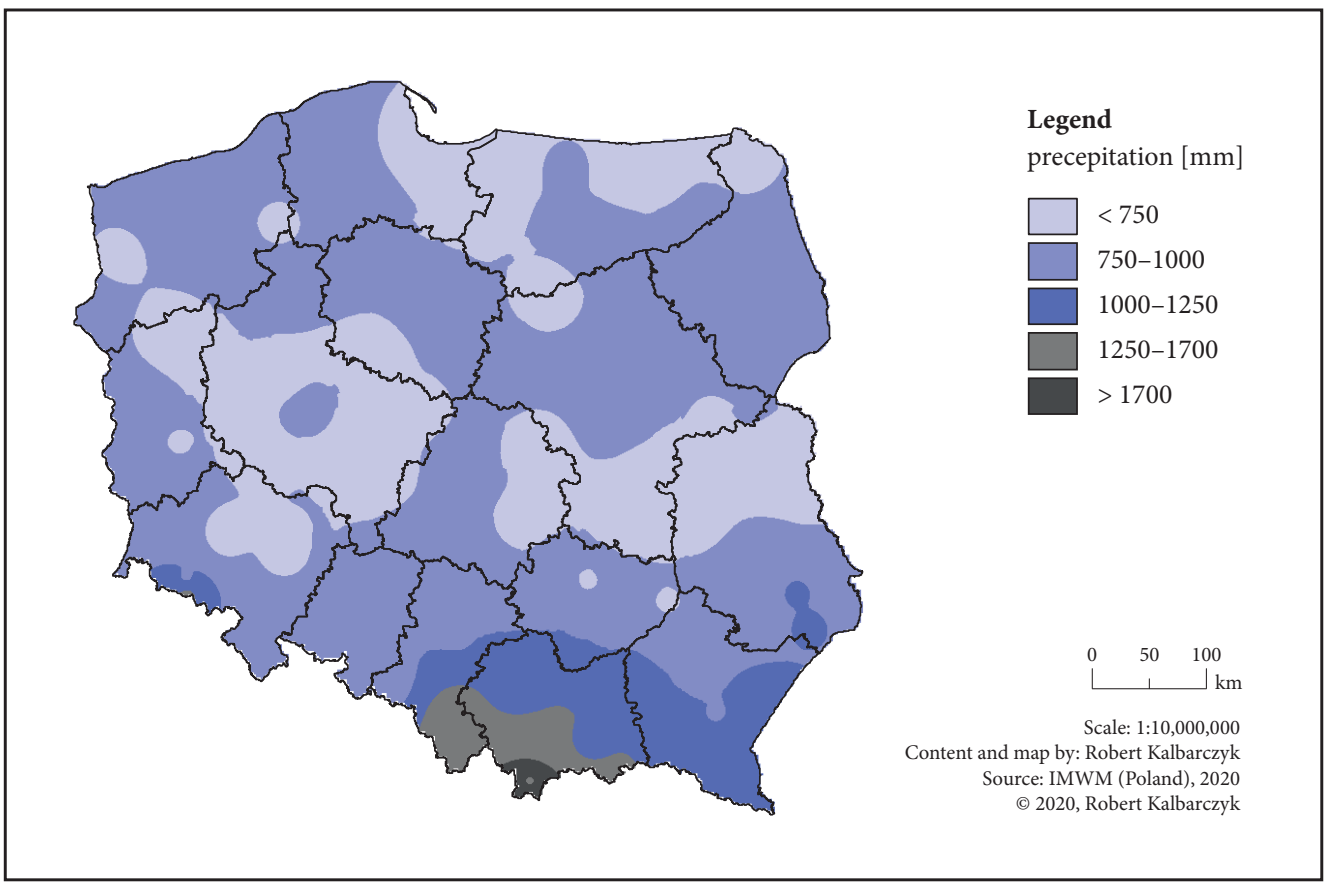

Figure 12: Spatial distribution of the highest annual precipitation totals in Poland in all the analyzed years, 1951-2018. 
(Cluster III) encompassed a small area in the south and the south-west of Poland. In the second half of the considered multi-year period, i.e. in 1985-2018, regions with a characteristic precipitation variability covered slightly different areas of Poland. In 1985-2018, the first Pr region was approximately 50\% larger than in 1951-1984 and covered the entire central strip of Poland up to the north-western and north-eastern parts of the country. The second Pr region shrank at the cost of the first region and covered areas only in the north and the south of the country; the third region, on the other hand, slightly shrank at the cost of the second region. As expected, in the whole analyzed multi-year period (1951-2018) the distribution of the distinguished precipitation regions was similar to the distributions in the first and second halves of the entire multi-year period. In 1951-2018, the first and second Pr regions covered almost the same area in terms of size. The first Pr region covered central Poland, while the second one covered the northern and southern parts. The third Pr region was situated in the south and the south-west of Poland and its area was slightly smaller than in 1951-1984.

In all the three analyzed multi-year periods, the stations of the lowest precipitation totals were classified as the first Pr region, while the stations of the highest totals were classified as the third Pr region (Table 4).

In 1951-1984, average precipitation totals were $\sim 550 \mathrm{~mm}$ in the first region, $\sim 650 \mathrm{~mm}$ in the second and $\sim 1310 \mathrm{~mm}$ in the third; in 1985-2018 these values were $\sim 577, \sim 713$ and $\sim 1237 \mathrm{~mm}$, respectively. In all the separated regions, lower Pr values in 1951-1984, in comparison with 1985-2018, occurred only in three months: March, May and September. Comparing the two examined sub-periods, a higher average standard deviation of Pr was calculated in 1985-2018 in Region I and Region III and in 1951-1984 in Region II. In particular months, Pr variability determined on the basis of the standard deviation was lower in as many as 10 months in 1951-1984 in Region II, 8 months in Region I, 6 months in Region III, and in 5 months, i.e. March, April, May, July and September, in all regions.

In the multi-year period of 1951-2018, average annual Pr oscillated from $567 \mathrm{~mm}$ in Region I to about $1272 \mathrm{~mm}$ in Region III (Table 4). In Region I, i.e. in central Poland, average monthly Pr values fluctuated from about 28 to $82 \mathrm{~mm}$; in Region II they fluctuated from about 33 to $95 \mathrm{~mm}$, and in Region III they fluctuated from about 73 to $172 \mathrm{~mm}$; the lowest totals occurred in February and the highest were in July. The highest variability of Pr in 1951-2018, as in the years 1951-1984 and 1985-2018, was noted in Region III.

Table 4: Characteristics ( $\bar{x} \pm$ SD) of precipitation totals in Poland by regions (I, II, III) in 1951-1984, 1985-2018, 1951-2018.

\begin{tabular}{|c|c|c|c|c|c|c|c|c|c|}
\hline \multirow[t]{2}{*}{$\begin{array}{l}\text { Period / } \\
\text { month }\end{array}$} & \multicolumn{3}{|c|}{$\begin{array}{c}\text { 1951-1984 } \\
\text { Region }\end{array}$} & \multicolumn{3}{|c|}{$\begin{array}{c}\text { 1985-2018 } \\
\text { Region }\end{array}$} & \multicolumn{3}{|c|}{$\begin{array}{l}\text { 1951-2018 } \\
\text { Region }\end{array}$} \\
\hline & | & $\|$ & III & 1 & $\|$ & ||l & 1 & $\|$ & \|\| \\
\hline $\begin{array}{l}\text { January- } \\
\text { December }\end{array}$ & $549.7 \pm 28.6$ & $649.1 \pm 58.7$ & $1306.3 \pm 335.9$ & $577.1 \pm 44.6$ & $713.4 \pm 38.2$ & $1236.7 \pm 352.6$ & $567.0 \pm 36.4$ & $693.3 \pm 41.4$ & $1271.5 \pm 338.2$ \\
\hline January & $29.6 \pm 15.3$ & $38.4 \pm 19.4$ & $79.1 \pm 40.3$ & $33.5 \pm 18.3$ & $40.6 \pm 21.6$ & $73.6 \pm 40.3$ & $32.0 \pm 17.1$ & $40.5 \pm 21.4$ & $76.3 \pm 40.5$ \\
\hline February & $26.0 \pm 15.3$ & $31.0 \pm 18.5$ & $75.6 \pm 45.7$ & $28.6 \pm 14.7$ & $34.8 \pm 16.7$ & $69.4 \pm 34.7$ & $27.6 \pm 15.2$ & $33.3 \pm 18.2$ & $72.5 \pm 40.7$ \\
\hline March & $27.3 \pm 14.6$ & $33.3 \pm 18.3$ & $78.3 \pm 36.9$ & $35.1 \pm 17.4$ & $40.5 \pm 20.3$ & $79.3 \pm 38.2$ & $31.5 \pm 16.5$ & $37.6 \pm 20.2$ & $78.8 \pm 37.6$ \\
\hline April & $36.4 \pm 18.6$ & $41.8 \pm 22.8$ & $101.8 \pm 42.9$ & $35.8 \pm 20.5$ & $43.9 \pm 23.7$ & $84.3 \pm 44.6$ & $36.4 \pm 19.8$ & $43.1 \pm 23.9$ & $93.0 \pm 46.6$ \\
\hline May & $55.3 \pm 26.9$ & $60.5 \pm 29.4$ & $129.1 \pm 53.7$ & $57.3 \pm 29.5$ & $69.8 \pm 35.9$ & $130.7 \pm 66.1$ & $56.7 \pm 28.8$ & $64.4 \pm 31.9$ & $129.9 \pm 63.6$ \\
\hline June & $67.7 \pm 32.7$ & $76.6 \pm 36.0$ & $176.1 \pm 69.0$ & $67.7 \pm 34.7$ & $80.6 \pm 39.7$ & $147.9 \pm 61.9$ & $67.9 \pm 33.8$ & $80.2 \pm 38.4$ & $162.0 \pm 67.1$ \\
\hline July & $80.5 \pm 43.7$ & $90.0 \pm 48.1$ & $176.2 \pm 89.9$ & $82.6 \pm 47.3$ & $96.2 \pm 55.2$ & $168.3 \pm 93.5$ & $81.7 \pm 45.6$ & $95.0 \pm 52.2$ & $172.3 \pm 93.2$ \\
\hline August & $64.4 \pm 36.6$ & $75.3 \pm 39.8$ & $143.5 \pm 72.8$ & $64.8 \pm 37.1$ & $80.2 \pm 40.9$ & $125.7 \pm 70.1$ & $65.0 \pm 37.0$ & $79.1 \pm 41.0$ & $134.6 \pm 71.8$ \\
\hline September & $45.6 \pm 27.6$ & $58.1 \pm 31.5$ & $93.6 \pm 48.2$ & $52.4 \pm 31.8$ & $72.7 \pm 41.8$ & $113.0 \pm 64.1$ & $49.5 \pm 29.9$ & $66.5 \pm 37.2$ & $103.3 \pm 57.6$ \\
\hline October & $40.7 \pm 34.2$ & $50.6 \pm 37.6$ & $81.0 \pm 53.5$ & $40.1 \pm 27.3$ & $56.8 \pm 36.3$ & $81.5 \pm 45.2$ & $40.5 \pm 30.7$ & $55.3 \pm 37.7$ & $81.3 \pm 49.4$ \\
\hline November & $39.9 \pm 20.7$ & $49.0 \pm 25.4$ & $87.7 \pm 43.3$ & $39.7 \pm 19.8$ & $49.6 \pm 25.7$ & $80.7 \pm 37.2$ & $40.1 \pm 20.3$ & $50.6 \pm 26.1$ & $84.2 \pm 40.5$ \\
\hline December & $36.2 \pm 19.7$ & $44.5 \pm 23.4$ & $84.6 \pm 37.8$ & $39.5 \pm 18.6$ & $47.7 \pm 22.4$ & $82.1 \pm 42.7$ & $38.1 \pm 19.3$ & $47.6 \pm 23.4$ & $83.4 \pm 40.5$ \\
\hline
\end{tabular}


Robert Kalbarczyk, Eliza Kalbarczyk, Precipitation variability, trends and regions in Poland: Temporal and spatial...
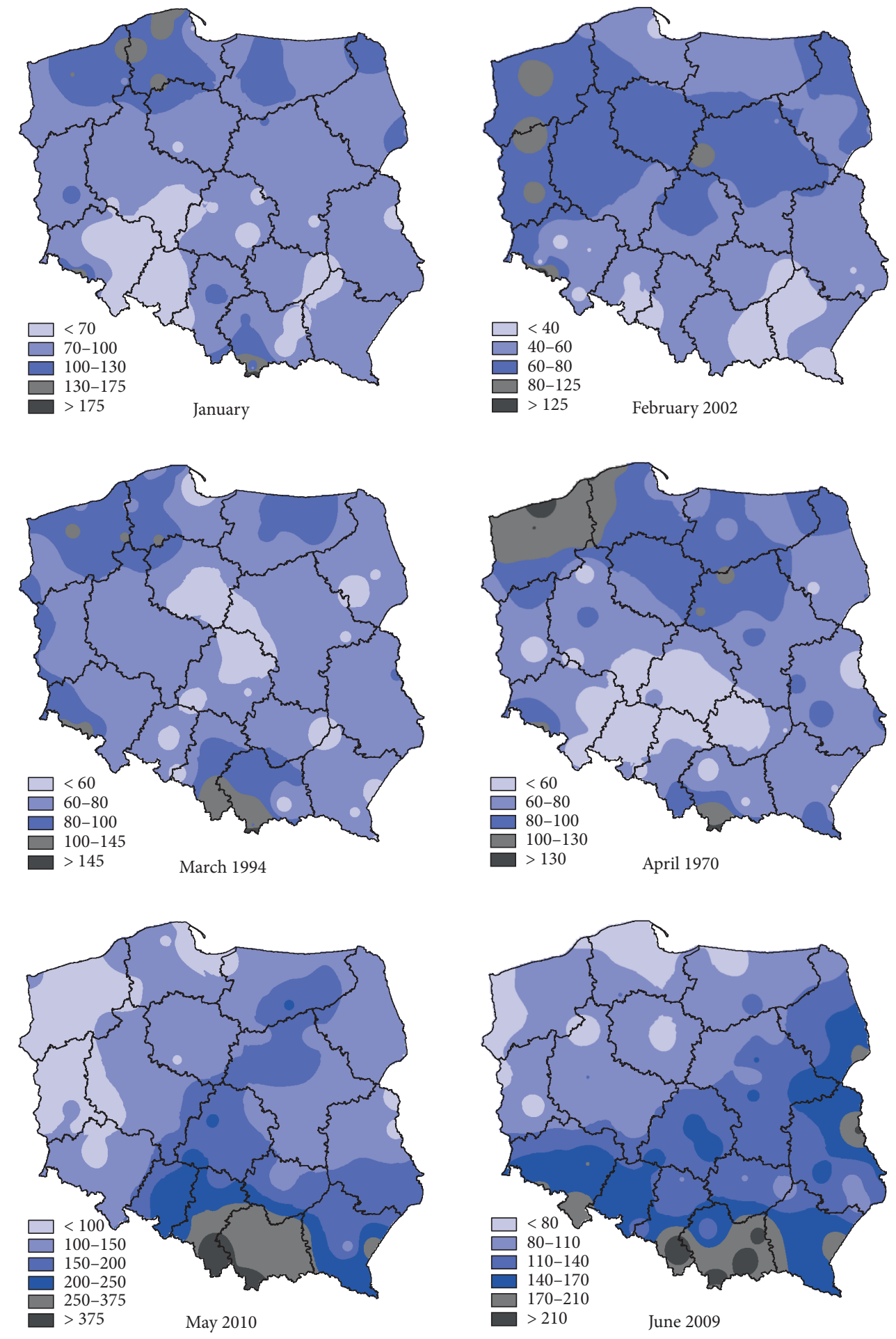


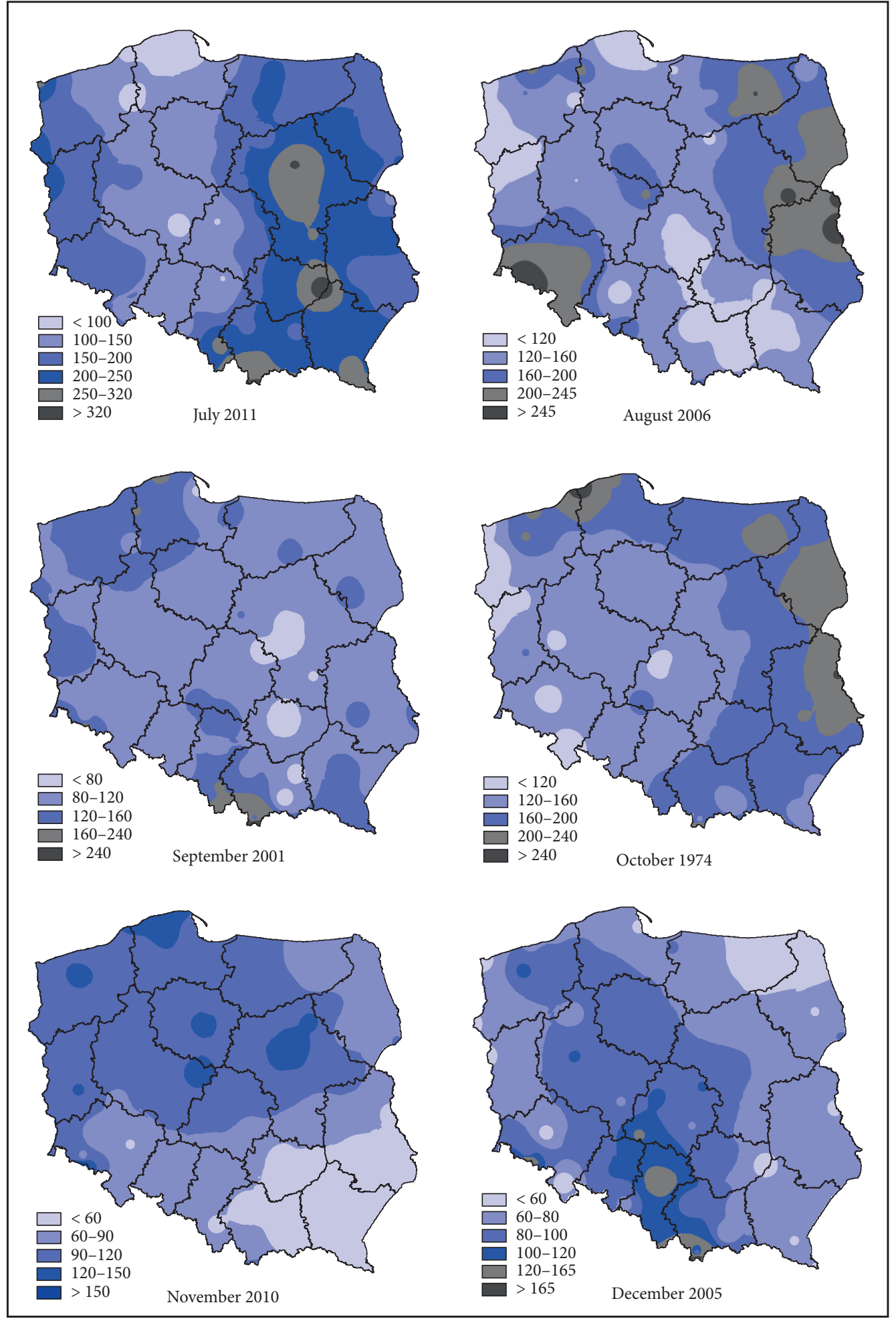


Robert Kalbarczyk, Eliza Kalbarczyk, Precipitation variability, trends and regions in Poland: Temporal and spatial...

a)

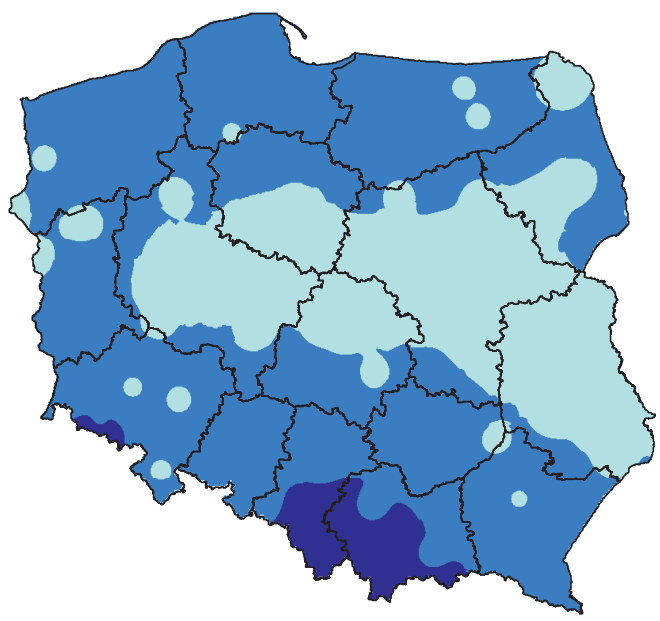

1951-1984

b)

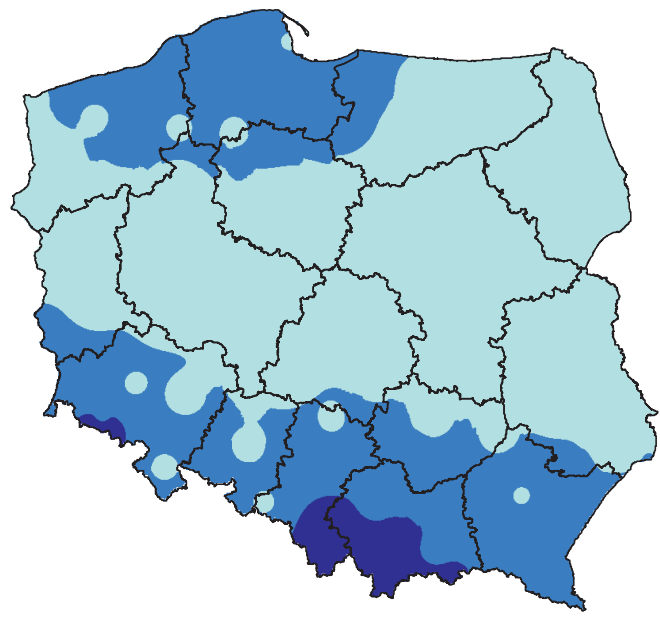

$1985-2018$

c)

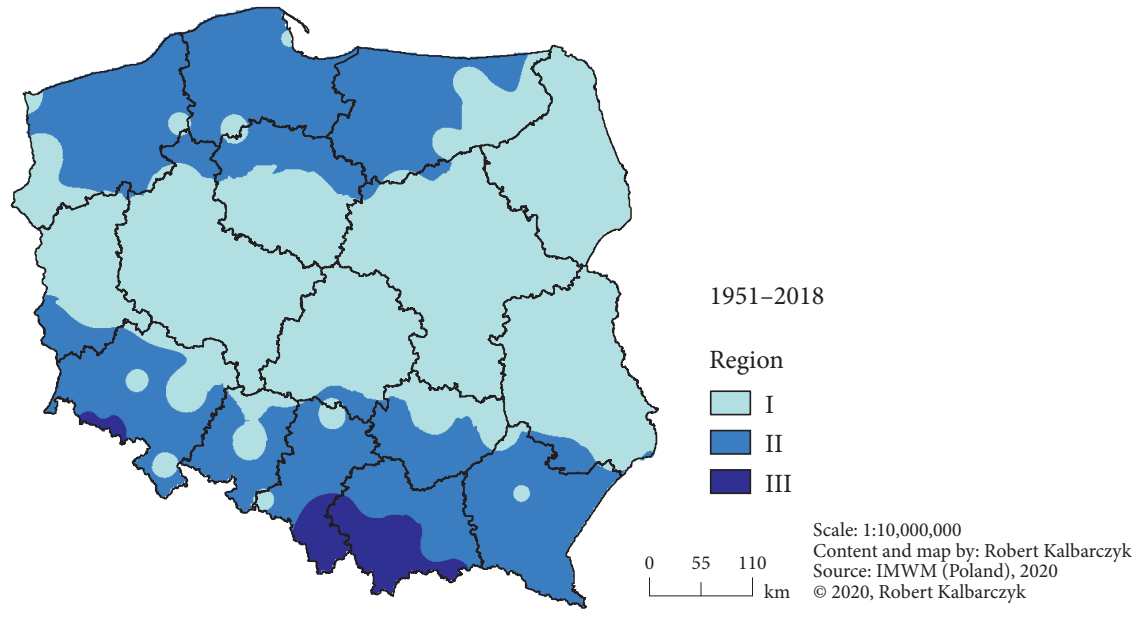


In autumn and winter months, the standard precipitation deviation was higher than in the spring and summer months and fluctuated from approximately 15 to $46 \mathrm{~mm}$ in Region I, from approximately 18 to $52 \mathrm{~mm}$ in Region II, with the lowest values in February and the highest in July; in Region III it oscillated from $\sim 38 \mathrm{~mm}$ in March to $\sim 93 \mathrm{~mm}$ in July.

\section{Discussion}

In Poland in the multi-year period the annual precipitation totals have changed significantly only in some areas of the country. In the south-east, central-east and north-west Poland, precipitation increased significantly, while the sum of precipitation was only locally reduced in south-west Poland. An increase in precipitation totals was confirmed only regionally. The observed significant positive increase in Pr in March had the biggest spatial range. The high increase in precipitation in March and the slight increase in annual precipitation totals in Poland in 1951-2013 were also confirmed by Szwed (2018).

A decrease in monthly precipitation totals was also frequent in some regions. Regional differences related to the trends of precipitation totals and the number of days with precipitation are a very common phenomenon. In Slovakia, regional differences in the temporal distribution of precipitation were shown by Labudová, Faško and Ivaňáková (2015); in Czechia, some regional differentiation in annual precipitation totals of daily maxima was also found (Květoň and Žák 2008). Some examples of regional differences in precipitation variability can also be found in studies by, for example, Skowera, Kopcińska and Kopeć (2014), Tošić et al. (2016), Kivinen et al. (2017) and Pathak et al. (2018).

In the examined 1951-2018 period, differences between the lowest and highest values of annual and monthly precipitation totals and the long-term average (norm) were very high. The highest annual precipitation total in Poland was recorded in 2010 and constituted $~ 135 \%$ of the norm. The highest monthly precipitation total constituted from about $164 \%$ in June (2009) to as much as about $355 \%$ in October (1974) of the multi-year monthly values. The lowest annual precipitation total in Poland, which was recorded in 1982 , constituted $\sim 72 \%$ of the multi-year annual precipitation. In particular months, precipitation totals constituted from as little as about $6 \%$ of the monthly norm in October 1951 to about $51 \%$ of the norm in June 1976. Although undertaken quite often, studies on values that deviate from the norm are still a challenge for researchers (Hundecha and Bárdossy 2005; Młyński, Cebulska and Wałęga 2018; Kalbarczyk and Kalbarczyk 2020b). Differences in the extent of atmospheric precipitation in Poland are primarily explained by the effect of certain types of atmospheric circulation; high importance is attributed to cloud cover (Degirmendžić, Kożuchowski and Żmudzka 2004; Żmudzka 2009; Twardosz, Niedźwiedź and Łupikasza 2011; Młyński, Cebulska and Wałęgaet 2018). For extreme phenomena it is difficult to prove the significance of a trend and regularities in the development of a given phenomenon (Pfeifer et al. 2015; Zeyaeyan et al. 2017). The observed differences in temporal distribution of precipitation totals between particular years result in irregular periods of drought and excessive precipitation, whose negative social and economic effects cannot be prevented (Kundzewicz, Radziejewski and Pińskwar 2006; Dumrul and Kilicarslan 2017; Brázdil et al. 2019). According to some researchers, the frequency of droughts in Poland is increasing and will continue rise until the end of the century (Kalbarczyk 2010; Kuchar and Iwański 2013; Somorowska 2016). Similar predictions concerning the increased intensification of drought conditions until 2100 have been made for, among others, California (Pathak et al. 2018), South Europe and North Africa (Caloiero, Caloiero and Frustaci 2018), and Thuringia in summer (Krause and Hanisch 2007). On the other hand, North Europe is expected to experience increased precipitation (Szwed et al. 2010). It is also reported that in spring Poland may expect an increase in precipitation (Mezghani et al. 2017).

Spatial distribution of annual precipitation totals in Poland shows a clear regularity. The lowest precipitation is characteristic of the central part of the country and increases northwards and southwards, with maximum values in the southernmost mountain areas. The determined precipitation regions display a fairly close similarity to the pluviothermal regions of Poland presented in Schmuck's (1965) as well as in Ziernicka-Wojtaszek and Zawora's (2008); the fundamental difference is the range of the lowest precipitation region reaching also the north-east of the country. In the Köppen's classification nearly the whole Poland is located in the Dfb zone, only a small fragment in the south is included in the climatic zone Dfc (Beck et al. 2018). Thus, the present regionalization provides additional information about spatial differences of precipitation in Poland. In particular months and seasons, spatial distribution of precipitation totals slightly diverge from this regularity; however, the areas with the lowest precipitation totals are continually 
Robert Kalbarczyk, Eliza Kalbarczyk, Precipitation variability, trends and regions in Poland: Temporal and spatial...

located in the strip of central lowlands with a shift to the west or east of the country. The highest monthly $\mathrm{Pr}$ values in the examined multi-year period occurred in various parts of the country, most frequently in the south of Poland. This kind of spatial distribution of precipitation in Poland is consistent with previous research studies conducted on the basis of different multi-year periods, as well as research on the early decades of the $20^{\text {th }}$ century (Twaróg 2016; Szwejkowski et al. 2017; Szwed 2018); this indicates stable regularities of Poland's spatial distribution of precipitation.

The determined precipitation regions may be useful for climatic risk management and preparation of regional and local adaptation plans aimed at balancing the effects of climate change (Twaróg 2016; Kalbarczyk and Kalbarczyk 2020a).

\section{Conclusion}

In Poland, average annual precipitation totals in 1951-2018 were only $\sim 634 \mathrm{~mm}$ and fluctuated from $<550 \mathrm{~mm}$ in the central part of the country to $>1300 \mathrm{~mm}$ in the south. The lowest average monthly precipitation $(\operatorname{Pr})$, was observed in February and was about 2.9 times as low as the highest average values observed in July. The highest variability of $\mathrm{Pr}$, both annual and monthly, usually occurred in the areas of the highest precipitation totals, primarily in the south of Poland.

In 1951-2018, in most parts of Poland apart from the south-west, annual precipitation totals rose year by year, but a significant increase of at least at a level of $\alpha \leq 0.1$ was found only in small areas in the northwest, central-west and south-east. This increase was caused by the rising Pr in March which occurred mainly in northern and central Poland.

Extreme annual precipitation totals in Poland occurred in 1982 and 2010. They constituted about 72\% and $134 \%$ of the norm, respectively. The lowest monthly Pr, which constituted only $\sim 6 \%$ of the norm, was recorded in October 1951; the highest monthly Pr, which constituted as much as $\sim 355 \%$ of the norm, was recorded in October 1974.

In the months of the lowest $\operatorname{Pr}$ (dry months), the average number of days without precipitation varied from about 22 days in June 1976 to 29 days in October 1951; in the months of the highest Pr (wet months), it varied from 6 days in January 2007 to 11 days in July 2011, April 1970 and February 2002. In the months with the lowest precipitation, the average number of days with precipitation of $>5 \mathrm{~mm}$ and the average number of days with precipitation of $>10 \mathrm{~mm}$ were mostly observed in June and amounted to 2.8 and 1.2 days, respectively. Spatial distribution of the lowest and highest Pr in particular months of the year in comparison with average multi-year values differed not only in precipitation totals but also in spatial distribution, which mostly resembled a latitudinal arrangement in the case of dry months or an irregular arrangement in wet months.

Three precipitation regions were distinguished in Poland on the basis of precipitation variability in each of the different multi-year periods: 1951-1984, 1985-2018, and 1951-2018. The lowest and least variable Pr values were classed as Region I, which in 1951-1984 covered the central-east part of Poland, whereas in 1985-2018 it was in the central, north-west and north-east parts of the country. The highest and most variable Pr was classed as Region III, which in all the analyzed multi-year periods was in the south-west and south Poland. The results may prove useful while planning water management measures, as well as in the management of flood risks and prevention of drought effects.

\section{References}

Beck, H. E., Zimmermann, N. E., McVicar, T. R., Vergopolan, N., Berg, A., Wood, E. F. 2018: Present and future Köppen-Geiger climate classification maps at 1-km resolution. Scientific Data 5. DOI: https://doi.org/ 10.1038/sdata.2018.214

Bochenek, W. 2020: Prawidłowości obiegu wody na obszarze beskidzko-pogórskim Karpat Zachodnich na przykładzie zlewni Bystrzanki w świetle zmian klimatu i działalności człowieka. Prace Geograficzne 271. DOI: https://doi.org/10.7163/9788361590XXX

Bokwa, A., Skowera, B. 2008: Wpływ rzeźby i użytkowania terenu na strukturę opadów atmosferycznych w okolicach Krakowa (1971-2005). Infrastruktura i Ekologia Terenów Wiejskich 5. Internet: http://agro.icm.edu.pl/ agro/element/bwmeta1.element.agro-3a1e6917-3a41-4d29-8adc-65726f69d93c (21. 1. 2021). 
Brázdil, R., Dobrovolný, P., Trnka, M., Řezníčková, L., Dolák, L., Kotyza, O. 2019: Extreme droughts and human responses to them: the Czech lands in the pre-instrumental period. Climate of the Past 15-1. DOI: https://doi.org/10.5194/cp-15-1-2019

Caloiero, T., Caloiero, P., Frustaci, F. 2018: Long-term precipitation trend analysis in Europe and in the Mediterranean basin. Water and Environment Journal 32-3. DOI: https://doi.org/10.1111/wej.12346

Chu, E., Anguelovski, I., Roberts, D. 2017: Climate adaptation as strategic urbanism: assessing opportunities and uncertainties for equity and inclusive development in cities. Cities 60. DOI: https://doi.org/ 10.1016/j.cities.2016.10.016

Degirmendžić, J., Kożuchowski, K., Żmudzka, E. 2004: Changes of air temperature and precipitation in Poland in the period 1951-2000 and their relationship to atmospheric circulation. International Journal of Climatology 24-3. DOI: https://doi.org/10.1002/joc.1010

Dumrul, Y., Kilicarslan, Z. 2017: Economic impacts of climate change on agriculture: empirical evidence from ARDL approach for Turkey. Journal of Business, Economics and Finance 6-4. DOI: http://doi.org/ 10.17261/Pressacademia.2017.766

Halimatou, T. A., Kalifa, T., Kyei-Baffour, N. 2017: Assessment of changing trends of daily precipitation and temperature extremes in Bamako and Ségou in Mali from 1961-2014. Weather and Climate Extremes 18. DOI: https://doi.org/10.1016/j.wace.2017.09.002

Hardoy, J., Hernández, I., Pacheco, J. A., Sierra, G. 2014: Institutionalizing climate change adaptation at municipal and state level in Chetumal and Quintana Roo, Mexico. Environment and Urbanization 26-1. DOI: https://doi.org/10.1177/0956247813519053

Hundecha, Y., Bárdossy, A. 2005: Trends in daily precipitation and temperature extremes across western Germany in the second half of the 20th century. International Journal of Climatology 25-9. DOI: https://doi.org/10.1002/joc.1182

Ilnicki, P., Farat, R., Górecki, K., Lewandowski, P. 2015: Long-term air temperature and precipitation variability in the Warta River catchment area. Journal of Water and Land Development 27. DOI: https://doi.org/ 10.1515/jwld-2015-0019

IMWM - Institute of Meteorology and Water Management. 2020. Internet: https://danepubliczne.imgw.pl/ apiinfo (18. 05. 2021).

IPCC 2014: Climate Change 2014: Impacts, adaptation, and vulnerability. Part A: Global and sectoral aspects. Contribution of working group II to the fifth assessment report of the Intergovernmental Panel on Climate Change. Cambridge, New York.

Kalbarczyk, E., Kalbarczyk, R. 2020a: Typology of climate change adaptation measures in Polish cities up to 2030. Land 9-10. DOI: https://doi.org/10.3390/land9100351

Kalbarczyk, R. 2010: Temporal and spatial diversity of the occurrence of atmospheric drought in Poland (1966-2005) and its effect of yield of pickling cucumber (Cucumis sativus L.). Spanish Journal of Agricultural Reserach 8-4.

Kalbarczyk, R., Kalbarczyk, E. 2020b: Meteorological conditions of the winter-time distribution of nitrogen oxides in Poznań: A proposal for a catalog of the pollutants variation. Urban Climate 33. DOI: https://doi.org/10.1016/j.uclim.2020.100649

Kalbarczyk, R., Kalbarczyk, E., Raszka, B. 2011: Risk to onion (Allium cepa L.) field cultivation in Poland from precipitation deficiency. Notulae Botanicae Horti Agrobotanici Cluj-Napoca 39-2. DOI: https://doi.org/ $10.15835 /$ nbha3926351

Kalbarczyk, R., Kalbarczyk, E., Ziemiańska, M., Raszka, B. 2018: Assessment of air thermal conditions in the lowland part of south-western Poland for agriculture development purposes. Atmosphere 9-6. DOI: https://doi.org/10.3390/atmos9060215

Kivinen, S., Rasmus, S., Jylhä, K., Laapas, M. 2017: Long-term climate trends and extreme events in Northern Fennoscandia (1914-2013). Climate 5-1. DOI: https://doi.org/10.3390/cli5010016

Krause, P., Hanisch, S. 2007: Prognostic simulation and analysis of the impact of climate change on the hydrological dynamics in Thuringia, Germany. Hydrology and Earth System Sciences Discussions 4. DOI: https://doi.org/10.5194/hessd-4-4037-2007

Kuchar, L., Iwański, S. 2013: Rainfall evaluation for crop production until 2050-2060 and selected climate change scenarios for north central Poland. Infrastruktura i Ekologia Terenów Wiejskich 1. Internet: http://www.infraeco.pl/en/art/a_17197.htm (21. 01.2021). 
Robert Kalbarczyk, Eliza Kalbarczyk, Precipitation variability, trends and regions in Poland: Temporal and spatial...

Kundzewicz, Z. W., Kozyra, J. 2011: Ograniczanie wpływu zagrożeń klimatycznych w odniesieniu do rolnictwa i obszarów wiejskich. Reducing impacts of climatic threats to agriculture and rural areas. Polish Journal of Agronomy 7. Internet: http://www.iung.pulawy.pl/PJA/wydane/7/PJA7_7.pdf (21.01.2021).

Kundzewicz, Z. W., Radziejewski, M., Pińskwar, I. 2006: Precipitation extremes in the changing climate of Europe. Climate Reserach 31-1. DOI: https://doi.org/10.3354/cr031051

Květoň, V., Žák, M. 2008: Extreme precipitation events in the Czech Republic in the context of climate change. Advances in Geosciences 14. DOI: https://doi.org/10.5194/adgeo-14-251-2008

Labudová, L., Faško, P., Ivaňáková, G. 2015: Changes in climate and changing climate regions in Slovakia. Moravian Geographical Reports 23-3. DOI: https://doi.org/10.1515/mgr-2015-0019

Łupikasza, E. B. 2017: Seasonal patterns and consistency of extreme precipitation trends in Europe, December 1950 to February 2008. Climate Research 72-3. DOI: https://doi.org/10.3354/cr01467

Majewski, G., Przewoźniczuk, W., Kleniewska, M. 2010: Precipitation at the meteorological station in Ursynów WULS - SGGW in 1960-2009. Scientific Review Engineering and Environmental Sciences 48-2. Internet: http://iks_pn.sggw.pl/PN48/A1/art1.pdf (15.12.2020).

Marcinkowski, P., Piniewski, M. 2018: Effect of climate change on sowing and harvest dates of spring barley and maize in Poland. International Agrophysics 32. DOI: https://doi.org/10.1515/intag-2017-0015

Marković, S. B., Ruman, A., Gavrilov, M. B., Stevens, T., Zorn, M., Komac, B., Perko, D. 2014: Modeling of the Aral and Caspian seas drying out influence to climate and environmental changes. Acta geographica Slovenica 54-1. DOI: https://ojs.zrc-sazu.si/ags/article/view/1907/1658

Mezghani, A., Dobler, A., Haugen, J. E., Benestad, R. E., Parding, K. M., Piniewski, M., Kardel, I., Kundzewicz, Z. W. 2017: CHASE-PL Climate Projection dataset over Poland - Bias adjustment of EURO-CORDEX simulations. Earth System Science Data 9. DOI: https://doi.org/10.5194/essd-9-905-2017

Młyński, D., Cebulska, M., Wałęga, A. 2018: Trends, variability, and seasonality of maximum annual daily precipitation in the Upper Vistula Basin, Poland. Atmosphere 9-8. DOI: https://doi.org/10.3390/atmos9080313

Olechnowicz-Bobrowska, B. 1970: Częstość dni z opadem w Polsce. Prace Geograficzne 86.

Olsson, J., Södling, J., Berg, P., Wern, L., Eronn, A. 2019: Short-duration rainfall extremes in Sweden: A regional analysis. Hydrology Research 50-3. DOI: https://doi.org/10.2166/nh.2019.073

Pathak, T. B., Maskey, M. L., Dahlberg, J. A., Kearns, F., Bali, K. M., Zaccaria, D. 2018: Climate change trends and impacts on California agriculture: a detailed review. Agronomy 8-3. DOI: https://doi.org/10.3390/ agronomy 8030025

Pedrozo-Acuña, A., Jorge, A., Magos-Hernández, J. A., Sánchez-Peralta, J. A., Amaro-Loza, A., Breña-Naranjo, A. 2017: Real-time and discrete precipitation monitoring in Mexico City: implementation and applicaton. International Symposium and Exhibition on Hydro-Environment Sensors and Software. Madrid.

Pfeifer, S., Bülow, K., Gobiet, A., Hänsler, A., Mudelsee, M., Otto, J., Rechid, D., Teichmann, C., Jacob, D. 2015: Robustness of ensemble climate projections analyzed with climate signal maps: seasonal and extreme precipitation for Germany. Atmosphere 6-5. DOI: https://doi.org/10.3390/atmos6050677

Radzka, E., Jankowski, K., Jankowska, J. 2019: Effects of rainfall shortage and climatic water balance on agriculture. Applied Ecology and Environmental Research 17-4. DOI: https:/doi.org/10.15666/aeer/ 1704_76677678

Reckien, D., Flacke, J., Olazabal, M., Heidrich, O. 2015: The influence of drivers and barriers on urban adaptation and mitigation plans-an empirical analysis of European cities. PLoS ONE 10-8. DOI: https://doi.org/10.1371/journal.pone.0135597

Schmuck, A. 1965: Regiony pluwiotermiczne Polski. Czasopismo Geograficzne 36-3.

Skowera, B., Kopcińska, J., Kopeć, B. 2014: Changes in thermal and precipitation conditions in Poland in 1971-2010. Annals of Warsaw University of Life Sciences - SGGW, Land Reclamation 46-2. DOI: https://doi.org/10.2478/sggw-2014-0013

Somorowska, U. 2016: Changes in drought conditions in Poland over the past 60 years evaluated by the Standardized Precipitation-Evapotranspiration Index. Acta Geophysica 64. DOI: https:/doi.org/10.1515/ acgeo-2016-0110

Stefanova, A., Hesse, C., Krysanova, V., Volk, M. 2019: Assessment of Socio-Economic and Climate Change Impacts on Water Resources in Four European Lagoon Catchments. Environmental Management 64. DOI: https://doi.org/10.1007/s00267-019-01188-1 
Szewrański, S., Chruściński, J., Kazak, J., Świąder, M., Tokarczyk-Dorociak, K., Żmuda, R. 2018: Pluvial flood risk assessment tool (PFRA) for rainwater management and adaptation to climate change in newly urbanised areas. Water 10-4. DOI: https://doi.org/10.3390/w10040386

Szwed, M. 2018: Variability of precipitation in Poland under climate change. Theoretical and Applied Climatology 135. DOI: https://doi.org/10.1007/s00704-018-2408-6

Szwed, M., Karg, G., Pińskwar, I., Radziejewski, M., Graczyk, D., Kędziora, A., Kundzewicz, Z. W. 2010: Climate change and its effect on agriculture, water resources and human health sectors in Poland. Natural Hazards and Earth System Sciences 10. DOI: https://doi.org/10.5194/nhess-10-1725-2010

Szwejkowski, Z., Kuchar, L., Dragańska, E., Cymes, I., Cymes, I. 2017: Current and future agroclimate conditions in Poland in perspective of climate change. Acta Agrophysica 24-2. Internet: http://www.actaagrophysica.org/Current-and-future-agroclimate-conditions-in-Poland-in-perspective-of-climatechange, 105059,0,2.html (15. 2. 2020).

Šebenik, U., Brilly, M., Šraj, M. 2017: Drought analysis using the standardized precipitation index (SPI). Acta geographica Slovenica 57-1. DOI: https://doi.org/10.3986/AGS.729

Tošić, I., Zorn, M., Ortar, J., Unkašević, M., Gavrilov, M. B., Marković, S. B. 2016: Annual and seasonal variability of precipitation and temperatures in Slovenia from 1961 to 2011. Atmospheric Research 168. DOI: https://doi.org/10.1016/j.atmosres.2015.09.014

Twardosz, R., Niedźwiedź, T., Łupikasza, E. 2011: The influence of atmospheric circulation on the type of precipitation (Krakow, southern Poland). Theoretical and Applied Climatology 104. DOI: https://doi.org/10.1007/s00704-010-0340-5

Twaróg, B. 2016: Characteristics of long-term variability of precipitation in the territory of Poland based on GPCC data for the years 1901-2010. IOSR Journal of Environmental Science, Toxicology and Food Technology 10-10. DOI: https://doi.org/10.9790/2402-1010015064

Żarski, J., Dudek, S., Kuśmierek-Tomaszewska, R., Bojar W., Knopik, L., Żarski, W. 2014: Agroklimatyczna ocena opadów atmosferycznych okresu wegetacyjnego w rejonie Bydgoszczy. Agro-climatological assessment of the growing season rainfall in the Bydgoszcz region. Infrastructure and Ecology of Rural Areas 2-3. Internet: http://dx.medra.org/10.14597/infraeco.2014.2.2.047 (15. 12. 2020).

Zeyaeyan, S., Fattahi, E., Ranjbar, A., Vazifedoust, M. 2017: Classification of rainfall warnings based on the TOPSIS method. Climate 5-2. DOI: https://doi.org/10.3390/cli5020033

Ziernicka-Wojtaszek A., Zawora T. 2008: Regionalizacja termiczno-opadowa Polski w okresie globalnego ocieplenia. Acta Agrophysica 11-3. Internet: http://www.acta-agrophysica.org/Thermal-precipitation-regionalisation-of-poland-during-the-global-warming-period,107594,0,2.html (21. 01. 2021).

Ziernicka-Wojtaszek, A., Kopcińska, J. 2020: Variation in atmospheric precipitation in Poland in the years 2001-2018. Atmosphere 11-8. DOI: https://doi.org/10.3390/atmos11080794

Żmudzka, E. 2009: Współczesne zmiany klimatu Polski. Acta Agrophysica 13-2. Internet: http://www.old.actaagrophysica.org/artykuly/acta_agrophysica/ActaAgr_167_2009_13_2_555.pdf (21. 01. 2021). 